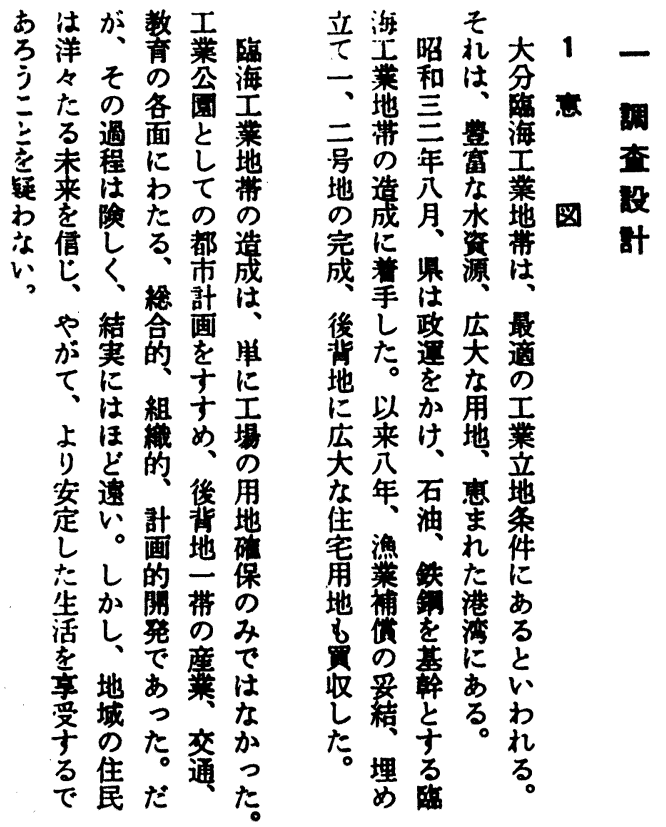

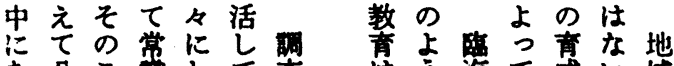

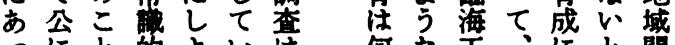
つにと的よいは何な在、にと開 てしをなうる、壳業そつし発 、た承域と人露果々地こいての

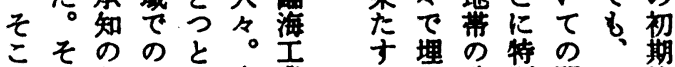

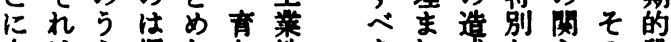
在はえ握たち地きれ成な心の段 住でで。つ带かばに间だ階 寸臨、あしつの る海過り、加あ造 々業去解替に の地回秋尃弆よ 人带にの留生る 閣のわ甘的蓗地 性造わさなの城 が成た䓡生の 没とり、率筑活。变 さう調に迄方。

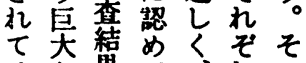
はな果て、れの な齿をいきを中 ら車あるわ赤宁 よよ心薄めは いると㞦に の卷杏る释

か来客恐地淩本 ○のをれ域開 いこ多注発 やれつな民方 5 \&

埋地の方先達 る域で数资て 人はする謷代をく

そいっ樭货る。則 措た わ5 く、と省少し

親

ま

分 元

瀶と

業 子

地带 ど

鶴 \&

崎 の

場 生

岩 
錐方で

箱大龸古

の分る

業海臨售

地 業

は、地

ま

传 浩

地 成

区忙

の旧

沿鹤

岸 㥓

二市明

带学治

で主

あ体

己

た緒

坚添

い の

た 地

石油 区
〈请料 1〉大分ili「鹤崎」
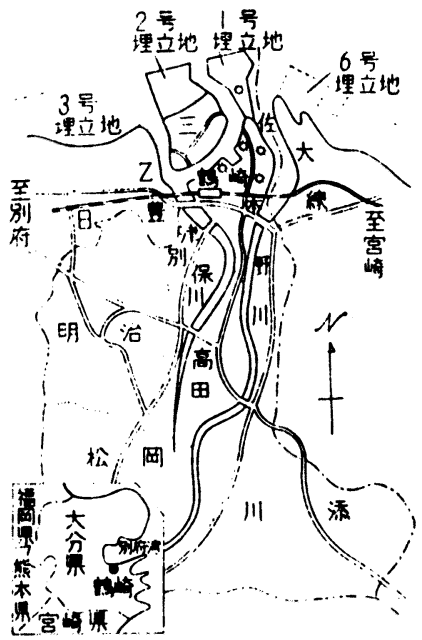

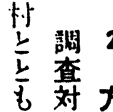

に象

大 地

分 域

市は法

に旧

䧻 鶴

し市

の

饮

料 昭

点和

旧 年

答市

市 隣

行接

政 五

区 访

画町

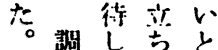

查厂止噢

はやま

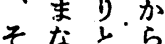

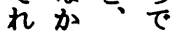

へっ何あ

のたをる

๖ kす

刺占き字

湤るかに

し 吉人

の 合に

意气謷

をと音

○ の

下䇨门

寸考観

的茄

ら に

机期

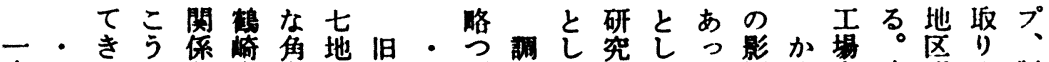

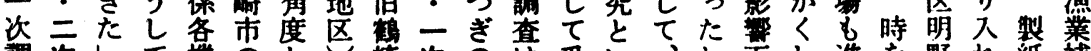

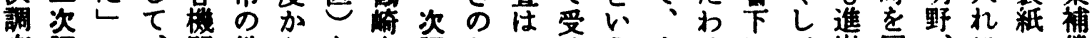

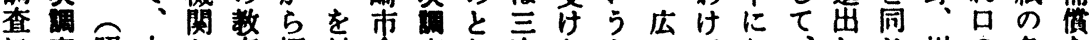

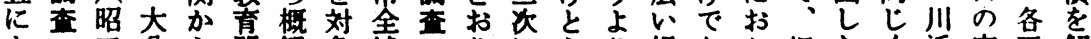

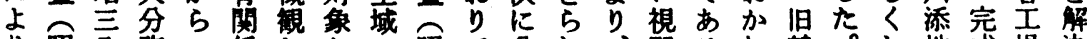

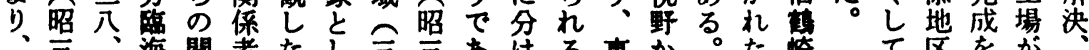

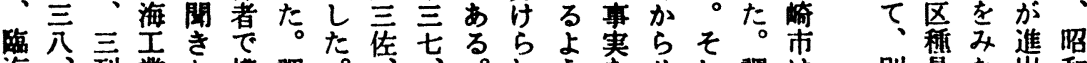

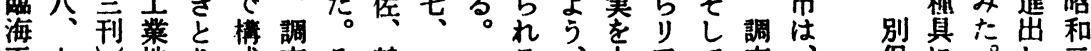

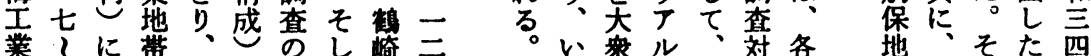

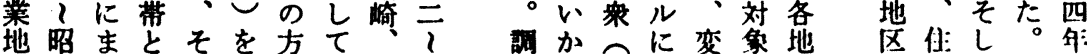

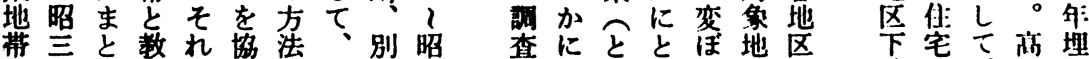

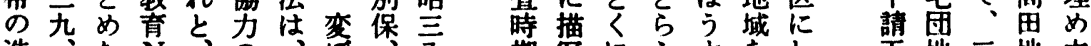

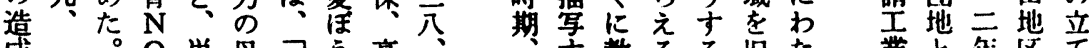

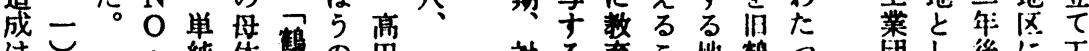

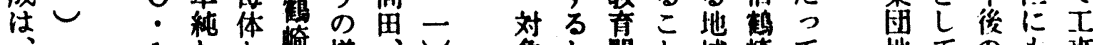

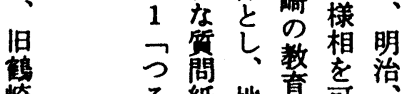

崎音紙地竞哥垛

全城查の吕るな

に変あ、会り川

さまわる多不多添

象加閶と域崎て 地てのも事 に係にの市、指の昭、に 内者し様と臨定用和大着

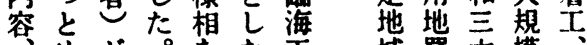
めが。をた工、城買六模 方た切調歴の業へ収年地间 法実查史も地蒂数しに業年

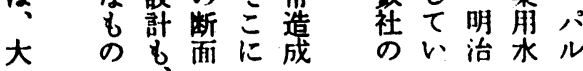




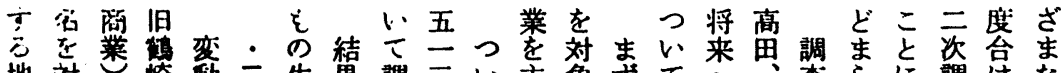

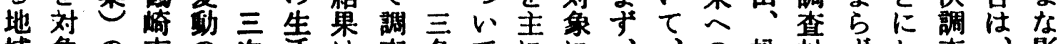
域象の市の次活は査名でにに、、の松対ずし査、影

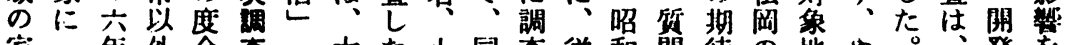
家年外合查不大少同查従和問待の地や。発を 庭母生ののの昭分。学年し事梨紙と四区がなるの年

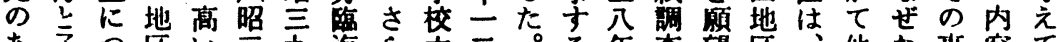
あ子つ区以无海 5 兵三方年查望区他な事容て りのいし、杂王に年月回産七に竞变のら実とい

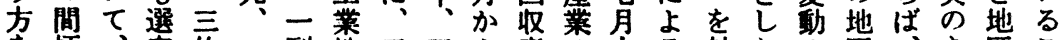

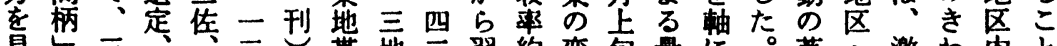

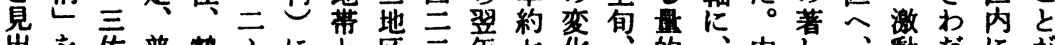

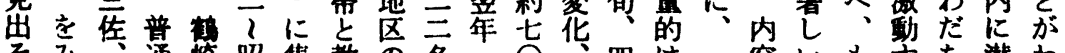

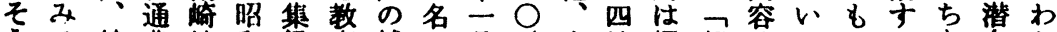
う籍基地和䟿音㭪の月\%生地握親は三はる在か

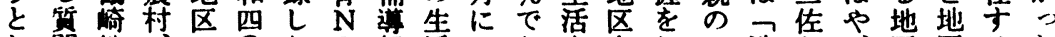
し閵地小の た紙区小家、。・織態けっ定住たま成、時の別諸

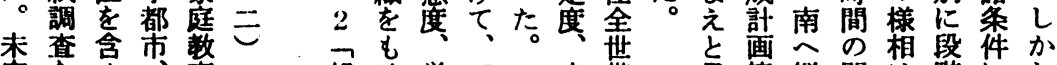

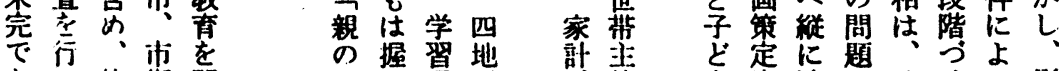

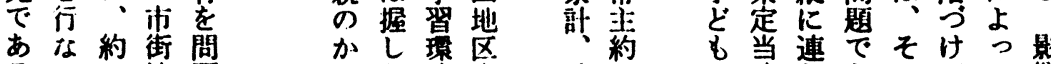

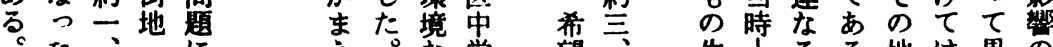
$\because$ 示。な学望方生】るる地は異の

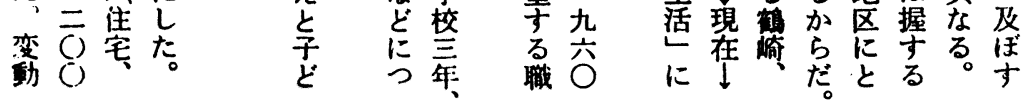

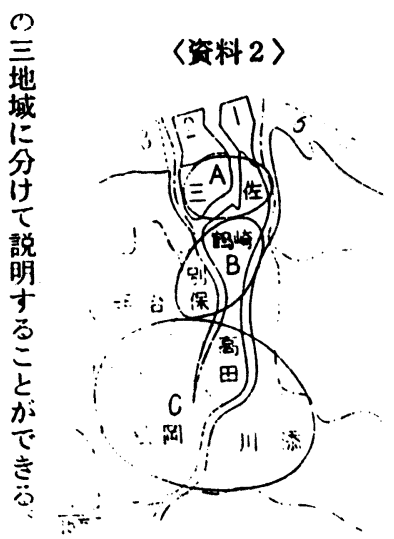

全汀大へな造大

城政分照盛分

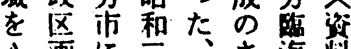
A 面に亥さ海料 B西合分年䧳志業 2

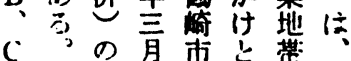

徽れで成 うにあし大 艺古るた分 (1) る う氐 费 票 亡 方た台带郋 きう地造 し来真注 住の後 民期枟背 告待業地 の 先 既 带 胎行成に 功 ᄂ 産薯 ら、生悉な 、活 体 ふ 地の举 ん 城一改 囲 別切善 気 にをなを 特こど变

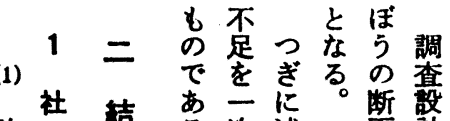
会 果
棵 $の$
塻考
る。次述
查る变

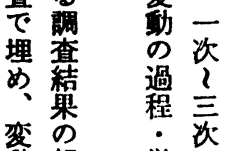
赫学 の
の告習計
事浩画
実、境に
召二 示
見次補玄
六調薄占
や查織に
上成家旧
う庭鹤
に主 の崎
編に市市
隹そ 方恋 


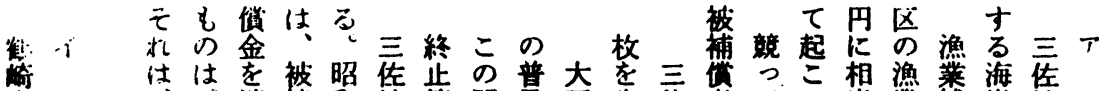

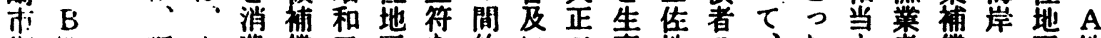

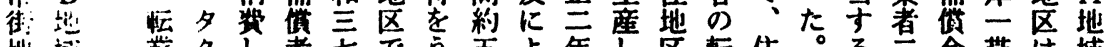

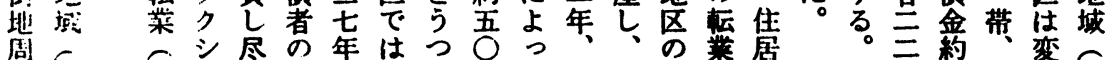

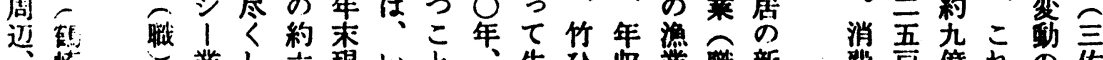

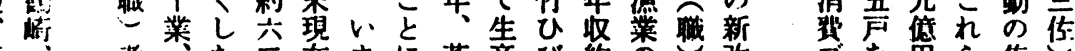

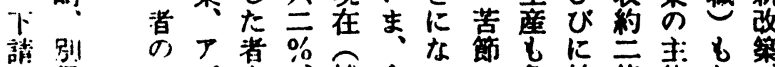

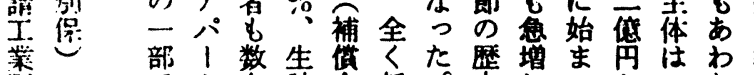

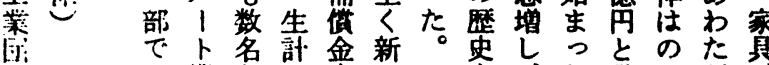

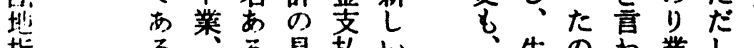

指方胃払々

定

地宊

$\underline{L}$

Hi]

保

地

軌通い告

生の業し

業道が荗

海業て あ行角

遇乘か年哲

菜占し、るなな品

今势焦

送员な目歴带く和開た

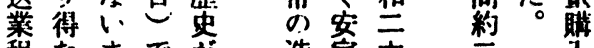

1 対 施点

么象支

はと払焦卡

ᄂ

恢たは艺る

程たまで始造定六 三人

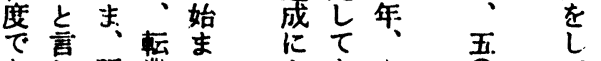

地一昭るば

区户和とく

を平三心大

中均四 5 な

あわ既業つよき

り热に補いて方たし

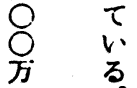

心四年印漁

に百占奂業

起阔强曾

加始烈金

亦

ప

() 望

符十しル

$\tau$

反别の、地

地筑〈资料 3〉

ウ 音别售数かの下、当别の以価

の当保が社し、复蛊る約保、下、下

地転用移㲜件数

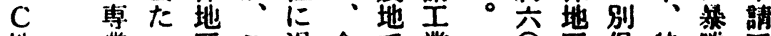

地菜气区こ過企で業

城费てのとき業あ団

家の焦さな皇る地

高に身良占進。指

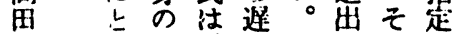

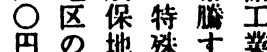

昭 $34 \sim 36$

で艆区なる囷

あ地に条

っのつ件

t地い等

明て岂地势六域

治河方地いな荈割と

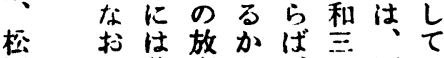

间苦整后北别の

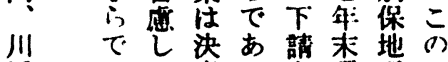

添 あて意る。企現区一 引、怘。業在集带 るた索芒は こも さ势地所

のの 交確有一

地、灾保亡四

保殁

そはみす

れ、当か

加昭机

公和兰

年吾竞

後年: 誹

現 筧

在州落

区将算心なー

的脰地 热 る 店

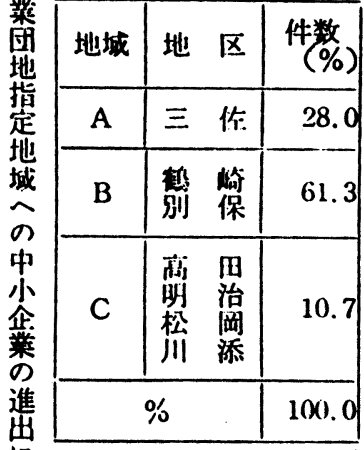

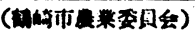

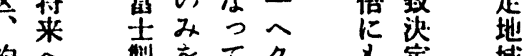

約众製をてク综城

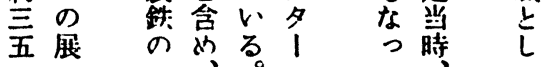

い住れには地る 便

き宅は多こ枟书了

おの、。の捅り

い新商地移、に 


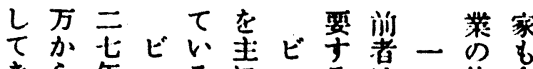
七き方年三るに二る星っ体多

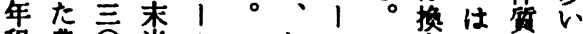

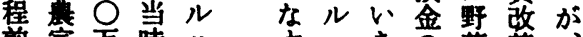
前家方時八十公き金萻 に円吕

高とにとス

田っな言の

地てるわ設

区は。れ借

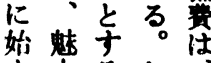

ま力るし

つのとか 施

だるこし、当

二机反り

1策ま当二

ル㹈でた五

、ウお摡の来大

きス以琵速力部

由に嶅は成老分

う上家早乘入は

りるのい墱れ旁

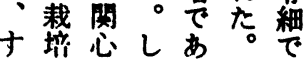

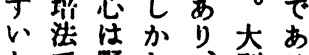

か、て野し、、別る

最る莱後まて彼

近。速者立三彼

は作成はつう注

〈疽料 4〉

稚家の典地所有

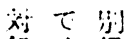

営主り吾

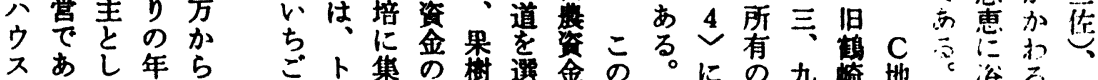

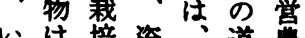

昭 37.12現灾以地

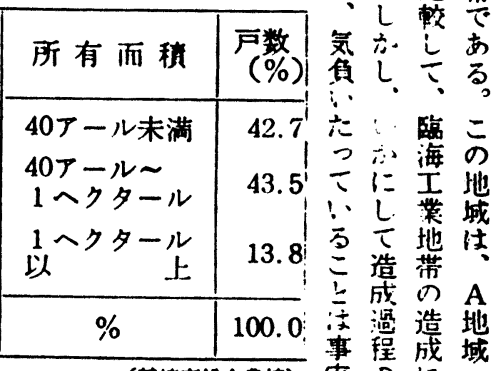
いは培道量

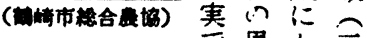

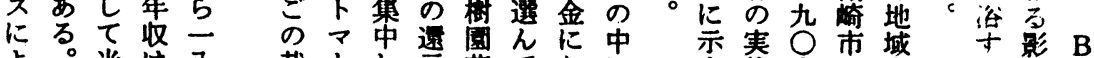

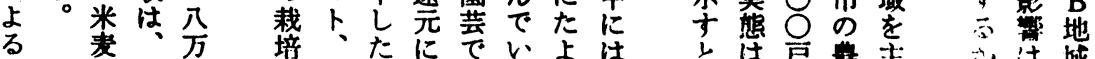

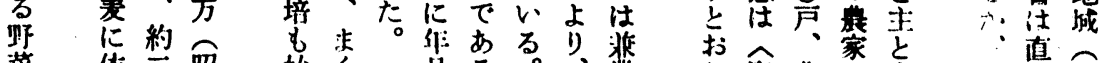

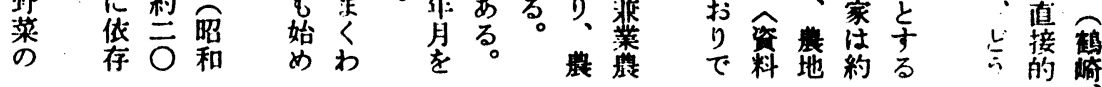

そ域や莱

以れ产地菜时

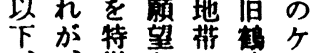

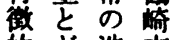

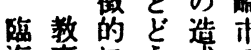

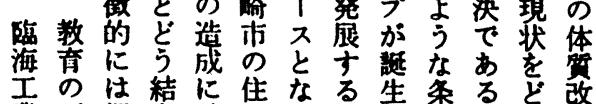

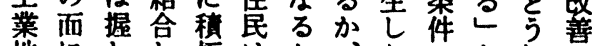

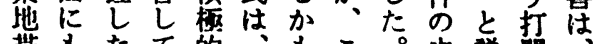

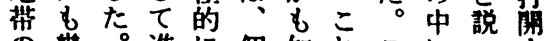

の幾。集に個知れこにい十

造うだ行反杂杂れあてる地

成かかし底人な、らついか城

にの、つしがいC砟てる、の

よ間子つたお

る題細あ。か

影をにるしれ

提调のかて

の供查かしい

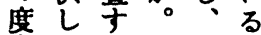
合てれ

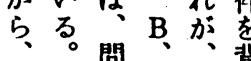

在閴 $\mathrm{C}$ 售暴

今 奥亏の輀

A 媣の生海

地 心地活
域西

のルつ

蛒 10

策 プ 部

のが、落

技復

課梅最

旺磄近

解 究

解段街

、階

一究
地究: 。
繁

政氐

指

满 選

者 宫

常<smiles>C[As]#[W]</smiles>

ᄀ

何道

りな゙落ほ

人

敗る

机野

家 栽

落注

る
多個

々人 C

閒虽域

あ゙ の

る。

過 ル

当八

な ウ

競

争に

によ

兼番

菜促

に培

脱 の

者炎
るこ産だ

に者思菜公污促

感は开已截

作最に俗方培

估安陷に“三法 有り危

管利 队険 C 松

理なす作地岡 作〈物城】

出付、它 - 少

荷菜只带添

老出者机价】

規荷に泣農明

制の左厂地治

す方石いはは

る法さ心。各

共を机。じ地

同とや価 三 区

化 万与格 1 人

のね必はが市市

要なし安ウ $\mathrm{C}$

からた定不地

起ながでで域

こくつあお お

つなて宁拉普

くる生方和度 


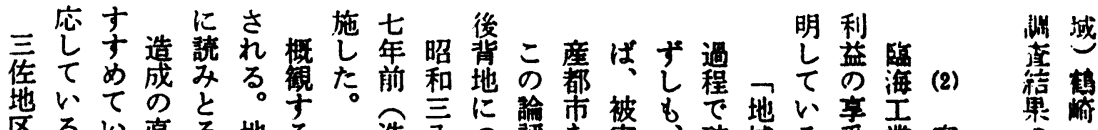

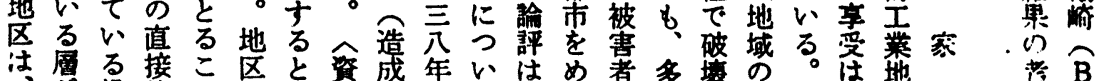

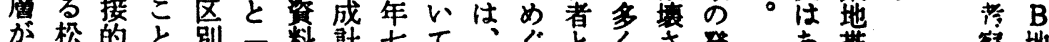

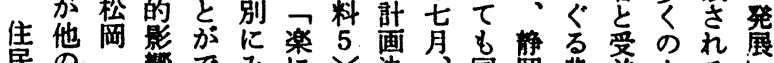

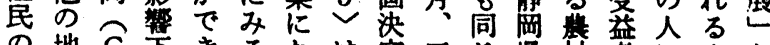

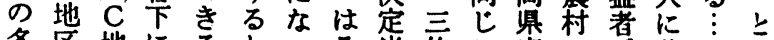

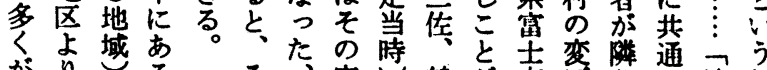

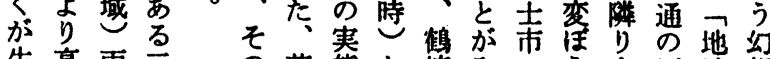

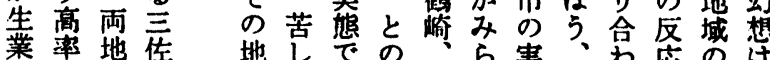

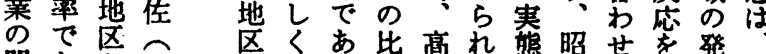

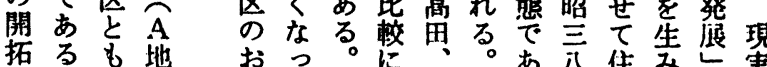

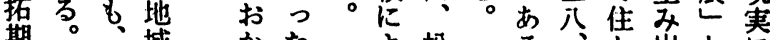
期

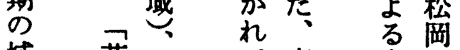

域苦

停勘

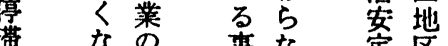

なの事な定区

ᄂ? 体

情々度の

あ 带

得造計染域

な得誠計吉

る 上改

る 存葶

特に龺带

街永実竞 る。出とに 大刊以主業 以: 注

$こ そ$ 加时 のの 间 こ地 立域

おたと各転が条 せ 今現地菜内件以 な後っ市職的過の 以、昭世的去よ 側ど和带が外七 面 方主起的年に で変分泉气間 あわ年従っいの住 るる七事てず成民 で月すくれ熟生 あこるるの度活 ろを産と条をの う比業于件示安 加較はるに十定 社た七と、か \&は 会埸年三わでそ 棵合前传占あ机 境と造鹪兵るれ゙ みと造䳡六それ れ

つ変計的当

めわ画高不度区

るつ決田を合の うた定皮的 え 当松 5 の で。㭙岡と均生

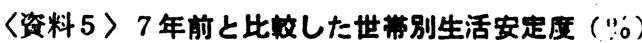
臨中ので想肪 海央ではの十 工公あな破广 業論る、壤め 地社。・は 带一心机核

直個少

氏

はに対只只

占模

\begin{tabular}{|c|c|c|c|c|c|c|}
\hline 安定 & $\begin{array}{l}\text { 变わら } \\
\text { よい }\end{array}$ & $\begin{array}{l}\text { 少し楽 } \\
\text { こなっ } \\
\text { た }\end{array}$ & $\begin{array}{l}\text { 変楽 } \\
\text { : }\end{array}$ & $\begin{array}{l}\text { つし苦 } \\
\text { くくな } \\
\text { った }\end{array}$ & 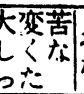 & $\begin{array}{l}\text { t心かi } \\
t: k\end{array}$ \\
\hline 三 佐 & 38.8 & 26.7 & 2.8 & 20.8 & 6.9 & $4.1)$ \\
\hline 崎 & 32.8 & 34.3 & 4.1 & 17.9 & 7.7 & 3.3 \\
\hline 高 & 36.0 & 38.8 & 3.8 & 14.3 & 4. $2 \mathrm{i}$ & 3.0 \\
\hline 松 岡 & 35.3 & 26.3 & 3.1 & 21.2 & 12.4 & 1.7 \\
\hline
\end{tabular}

(时38.7F,

よあ在体あブ।で C に背で

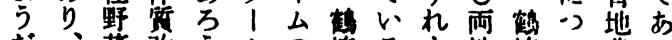

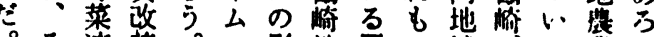
そ速棓。の影地偓子域た策门 の成の高波籍区夜楽の高段乞。 あ载先田に老の高に中思穊しま ら培達は乘受市以な閳の点二た

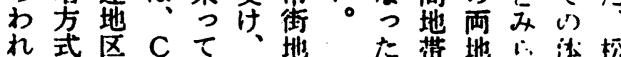

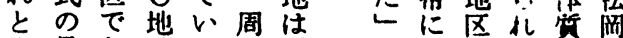
み最あ城る辺息あは无改

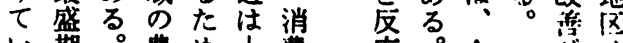

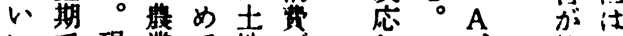

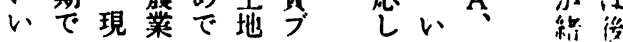


〈谈料 $\dot{e}\rangle$

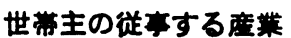

(\%)

\begin{tabular}{|c|c|c|c|c|c|c|c|c|c|}
\hline 域 & $\begin{array}{l}\text { 费 } \\
\text { 業 }\end{array}$ & $\begin{array}{l}\text { 林 } \\
\text { 莱 }\end{array}$ & $\begin{array}{l}\text { 漁 } \\
\text { 業 }\end{array}$ & $\begin{array}{l}\text { 鉱 } \\
\text { 業 }\end{array}$ & $\begin{array}{l}\text { 建 } \\
\text { 設 }\end{array}$ & $\begin{array}{l}\text { 製 } \\
\text { 造 }\end{array}$ & $\begin{array}{l}\text { 卸 } \\
\text { 売 }\end{array}$ & $\begin{array}{l}\text { 金保 } \\
\text { 融険 }\end{array}$ & $\begin{array}{l}\text { 丕 } \\
\text { 重 }\end{array}$ \\
\hline 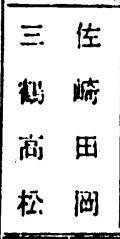 & $\begin{array}{r}19.9 \\
(19.5) \\
5.4 \\
(6.3) \\
50.8 \\
(64.7) \\
62.0 \\
(67.1) \\
\end{array}$ & $\begin{array}{c}1.0 \\
(1.2) \\
0.7 \\
(0.9) \\
0.3 \\
(0.4) \\
0.9 \\
(0.3)\end{array}$ & $\begin{array}{r}11.3 \\
(19.1) \\
0.5 \\
(0.6)\end{array}$ & $\begin{array}{l}(0.4) \\
(0.1)\end{array}$ & $\begin{array}{r}14.2 \\
(12.5) \\
7.5 \\
(6.9) \\
2.0 \\
(2.3) \\
5.3 \\
(2.4) \\
\end{array}$ & \begin{tabular}{r|}
7.1 \\
$(7.0)$ \\
5.3 \\
$(7.5)$ \\
4.5 \\
$(2.3)$ \\
2.1 \\
$(2.9)$
\end{tabular} & $\begin{array}{r}4.2 \\
(3.9) \\
9.1 \\
(9.3) \\
3.2 \\
(4.3) \\
4.8 \\
(3.5)\end{array}$ & $\begin{array}{r}0.3 \\
(0.1 \\
1 \\
(0.9) \\
\\
\end{array}$ & $\begin{array}{l}0.2 \\
(0) \\
0.2 \\
(0)\end{array}$ \\
\hline \multirow{2}{*}{ 域 } & 连通 & 醒ガ水 & サ & $-\quad$ & ス & 公 & $z$ & の & 他 \\
\hline & 鍮信 & 奴ス道 & 尃門 & 会社 & その他 & 務 & 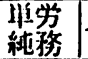 & その他 & \\
\hline 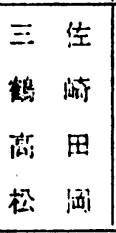 & $\begin{array}{r}3.2 \\
(3.0) \\
2.5 \\
(3.9) \\
1.6 \\
(1.2) \\
0.1 \\
(1.6) \\
\end{array}$ & $\begin{array}{r}0.2 \\
(0.2)\end{array}$ & $\begin{array}{r}2.1 \\
(1.4) \\
2.6 \\
(2.4) \\
1.0 \\
(0.8) \\
1.0 \\
(0.6)\end{array}$ & $\begin{array}{r}(17.7) \\
47.2 \\
(38.0) \\
19.9 \\
(10.9) \\
8.1 \\
(8.7)\end{array}$ & $\begin{array}{r}2.8 \\
(2.4) \\
5.8 \\
(4.4) \\
4.8 \\
(1.6) \\
2.6 \\
(1.9) \\
\end{array}$ & \begin{tabular}{r|}
7.6 \\
$10.8)$ \\
10.1 \\
16.0 \\
10.9 \\
10.9 \\
8.1 \\
$(7.4)$
\end{tabular} & $\begin{array}{r}4.0 \\
(1.4) \\
2.5 \\
(3.1) \\
1.0 \\
(0.8) \\
3.8 \\
(2.3)\end{array}$ & $\begin{array}{r}0.1 \\
(0.1)\end{array}$ & \\
\hline
\end{tabular}

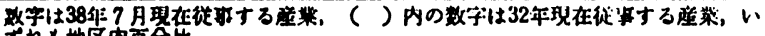
新地区内面分比

\begin{tabular}{|c|c|c|c|c|}
\hline & 7 & 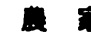 & & $(\%)$ \\
\hline 項 目 & 三 估 & 施 崎 & 高 田 & 烃 岡 \\
\hline 整程家 & 19.5 & 24.5 & 46.6 & 49.1 \\
\hline
\end{tabular}

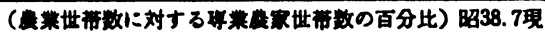

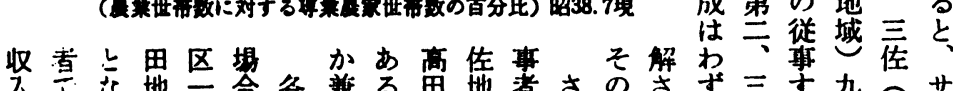

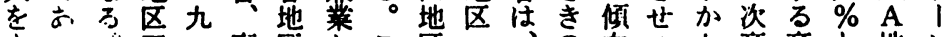

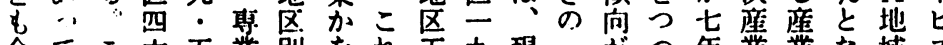

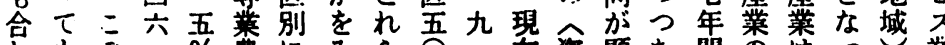

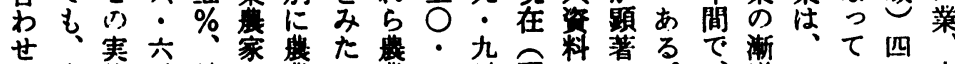

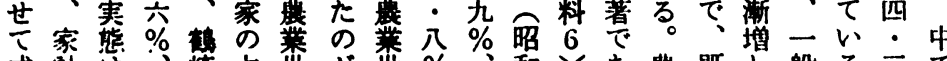

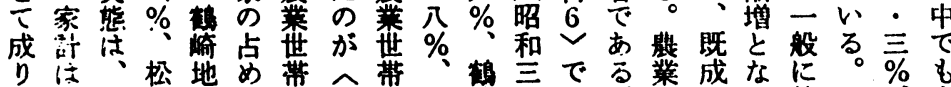

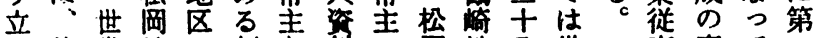
他带地三割老料の岡地入世年座下而 下方区四合二7家地区年带

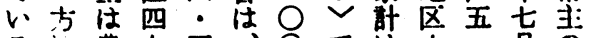

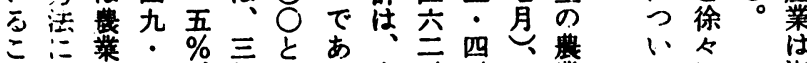

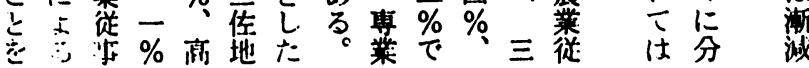
造 成 佳 (3) 訪 画 鶴 転 染崎菜 誻高部 侍苗 と松 昭岡 和の 変 年 七2 全た

現 在 o) 料 枈 で㧒 क 吉尔 解 
親のかまえと子どもの生活

〈资料 8 〉

世举主からみた安定しているように思える篗筆 （\%)

\begin{tabular}{|c|c|c|c|c|c|c|c|c|c|}
\hline 地域 & 㕮 & $\begin{array}{l}\text { 林 } \\
\text { 羒 }\end{array}$ & $\begin{array}{l}\text { 漁 } \\
\text { 業 }\end{array}$ & $\begin{array}{l}\text { 蚿 } \\
\text { 菜 }\end{array}$ & $\begin{array}{l}\text { 起 } \\
\text { 砓 }\end{array}$ & $\begin{array}{l}\text { 制 } \\
\text { 造 }\end{array}$ & $\begin{array}{l}\text { 铄 } \\
\text { 売 }\end{array}$ & $\begin{array}{l}\text { 金保 } \\
\text { 期除 }\end{array}$ & 歪 \\
\hline $\begin{array}{ll}\text { 三 } & \text { 佳 } \\
\text { 地 } & \text { 岎 } \\
\text { 高 } & \text { 田 } \\
\text { 松 } & \text { 岡 }\end{array}$ & $\begin{array}{l}1.3 \\
1.1 \\
4.7 \\
9.3\end{array}$ & & & & $\begin{array}{l}1.7 \\
0.4\end{array}$ & $\begin{array}{l}1.6 \\
5.3 \\
2.8 \\
5.5\end{array}$ & $\begin{array}{l}3.3 \\
4.0 \\
3.7 \\
0.6\end{array}$ & $\begin{array}{l}0.8 \\
1.3 \\
1.8 \\
0.6\end{array}$ & \\
\hline 和别 & 荤通 & $\begin{array}{l}\text { Uガ水 } \\
\text { 式ス道 }\end{array}$ & $\frac{\text { \# }}{\text { 專門 }}$ & $\frac{- \text { ヒ }}{\text { 会社 }}$ & その他 & 公 & 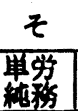 & $\frac{\text { の }}{\text { その他 }}$ & 他 \\
\hline 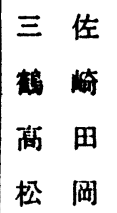 & $\begin{array}{l}1.7 \\
0.7\end{array}$ & & $\begin{array}{l}1.7 \\
1.3\end{array}$ & $\begin{array}{l}42.5 \\
38.3 \\
32.1 \\
46.9\end{array}$ & $\begin{array}{l}0.8 \\
2.9\end{array}$ & $\begin{array}{l}42.1 \\
43.2 \\
51.4 \\
32.5\end{array}$ & $\begin{array}{l}2.5 \\
0.7 \\
0.6\end{array}$ & 0.6 & \\
\hline
\end{tabular}

(昭38.7㪙)

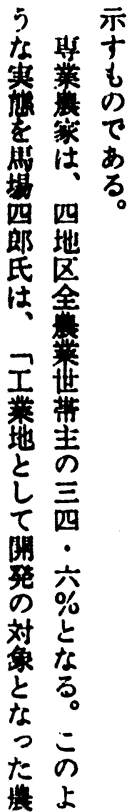

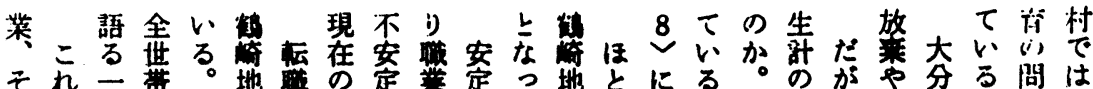

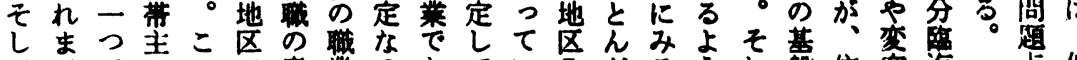
てでのの意策のあてい八とるう视整容海点例

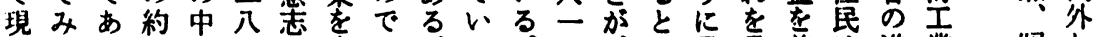

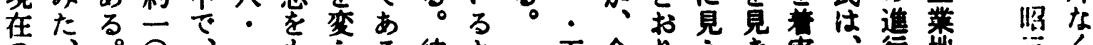

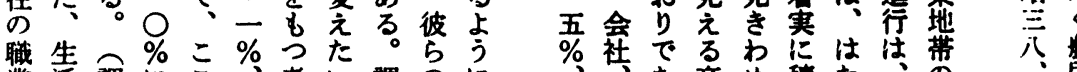

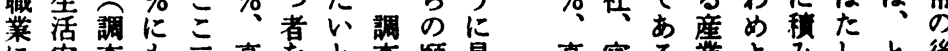

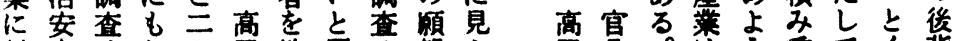
対定恃な界地反望え

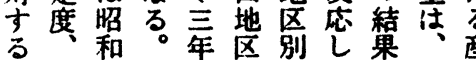

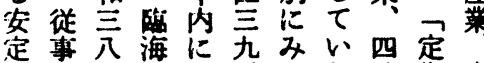
感导年工莿\%弓た地期

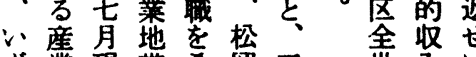

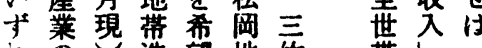
记穴造望地侄

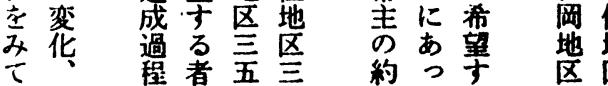

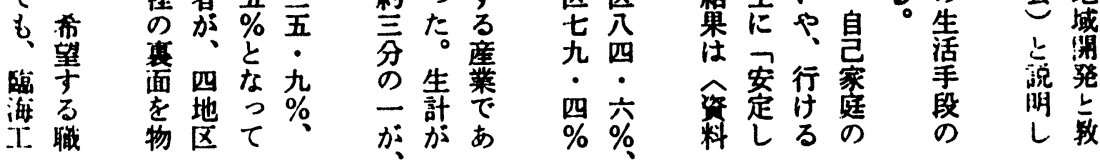

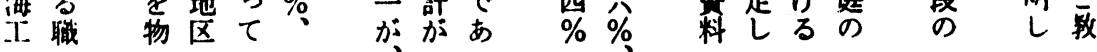




\begin{tabular}{|c|c|c|c|c|c|c|c|c|c|c|c|c|c|c|}
\hline 地蔏 & 费 & 林 & 漁 & 领 & 越 & 造 & $\begin{array}{l}\text { 卸 } \\
\text { 小 } \\
\text { 売 }\end{array}$ & $\begin{array}{l}\text { 金 } \\
\text { 保 } \\
\text { 保 }\end{array}$ & $\begin{array}{l}\text { 不 } \\
\text { 動 } \\
\text { 産 }\end{array}$ & $\begin{array}{l}\text { 運 } \\
\text { 通 } \\
\text { 檍 }\end{array}$ & $\begin{array}{l}\text { 雷 } \\
\dot{\text { カ }} \\
\text { ス }\end{array}$ & 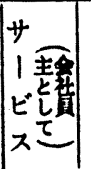 & 務 & $\begin{array}{l}\text { そ } \\
\text { の } \\
\text { 他 }\end{array}$ \\
\hline 三.估. & 5.5 & & 2.7 & & $\begin{array}{r}15.1 \\
5.5\end{array}$ & $\begin{array}{r}15.1 \\
7.8\end{array}$ & & $\begin{array}{l}1.4 \\
2.7\end{array}$ & & $\begin{array}{l}8.2 \\
3.1\end{array}$ & & & $\begin{array}{l}12.3 \\
10.2\end{array}$ & 11.0 \\
\hline
\end{tabular}

\section{(略32 38. 7枟入者)}

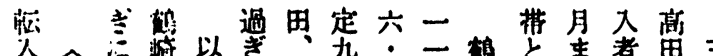

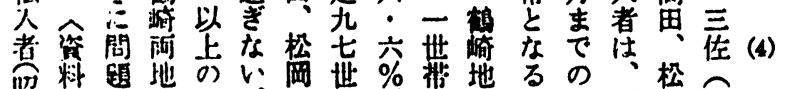

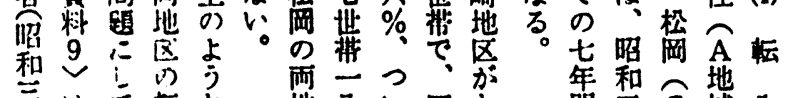

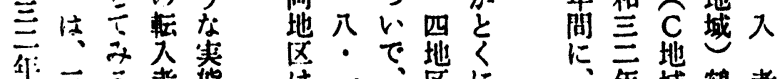

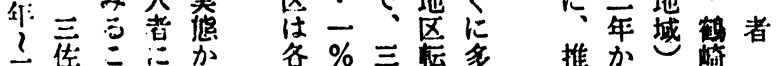

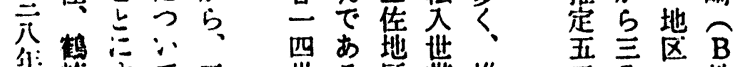

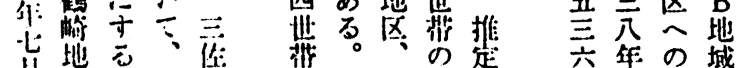

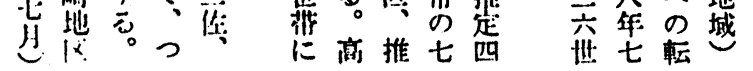

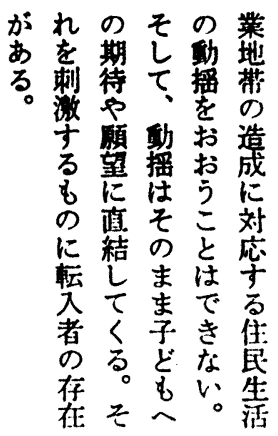

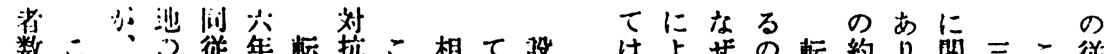

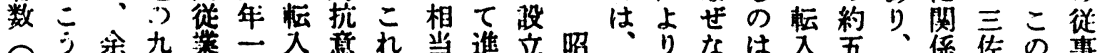

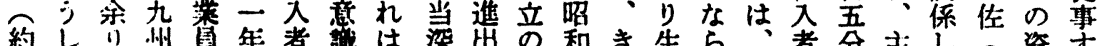

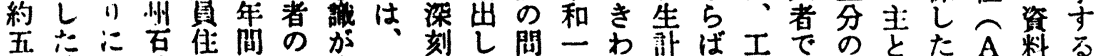

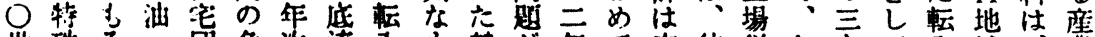

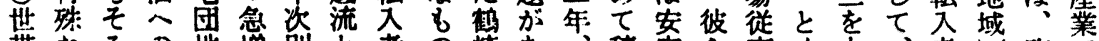

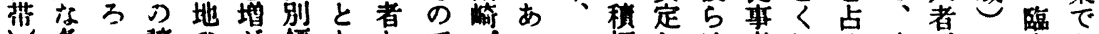

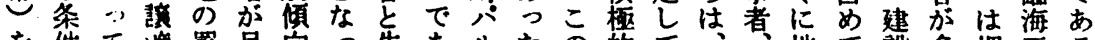

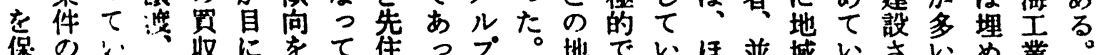
保の)收にをて售っプ。地で、ほ並城いさいめ業

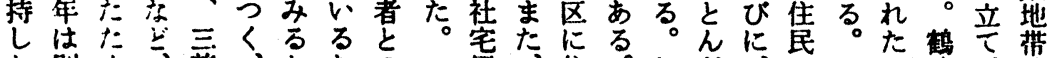

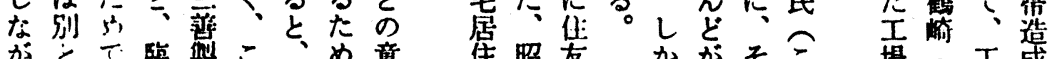

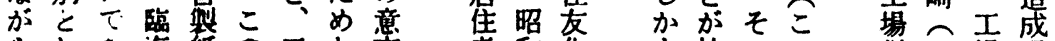

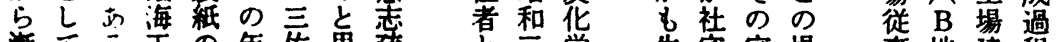

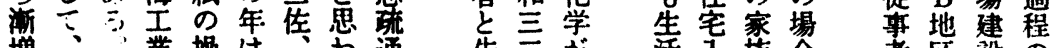

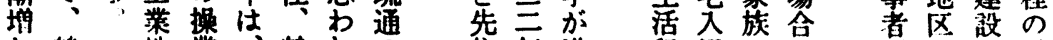

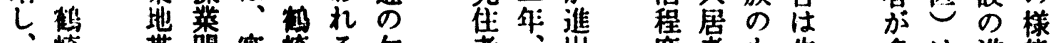

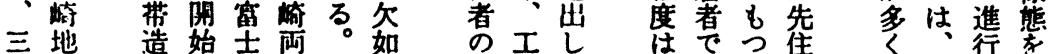

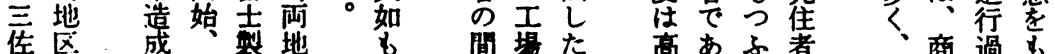

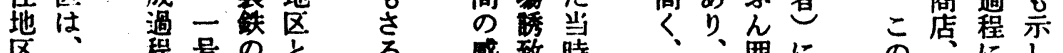

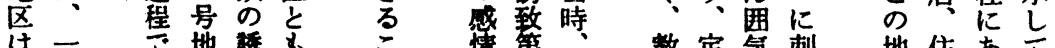

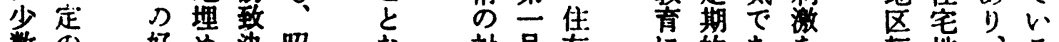

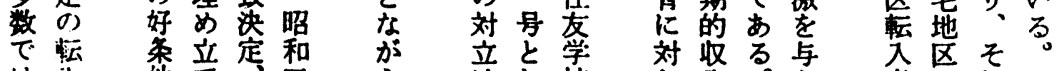

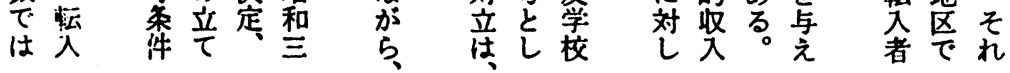




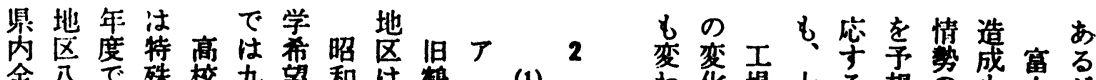
全八で䛈校九望和は鹤(1) (

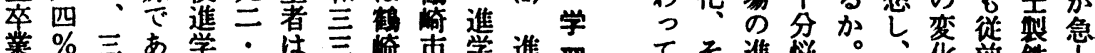

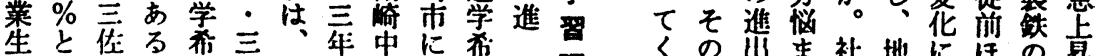

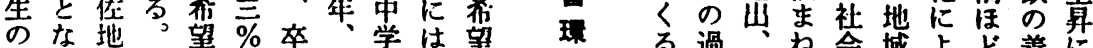

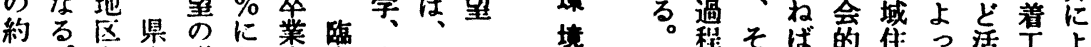
七。九立增な生海高鹤路㙂っで机な間售っ活志よ

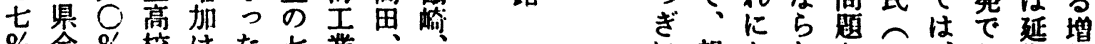
$\%$ 全\%校はた七業は、 で体、進、地大 あの鶴学県七:带岡東 り、昭嵣希内年三策地 、和地望の間\%定区三 各三区者一ので当はう 地入九般上あ時大の 区年克地的兵つの東中 と度 \%区僻率た两中学

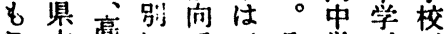
こ立离にで主そ学が范 れ高思市玄れ全校あ

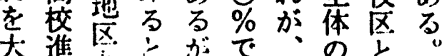

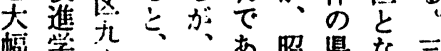
に学六昭こる照県な仿

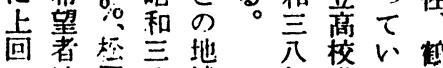

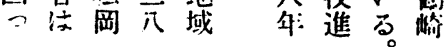

に親となとこるな期加 述たもいしの枟くさの ちな。場入机傾 るのうの合者むた向 学子㛉みはのし。 習ど業に先大ろこあ 琵气集量沾れる

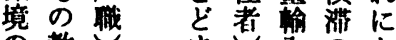

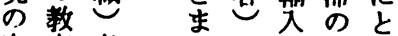
実卑者占は多状 悲にお倠な 対転、枟包保 そ寸入教入得あ臨 のる者育者るる游 二期間に。。I

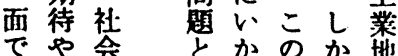
る嫄境望效乞し、带

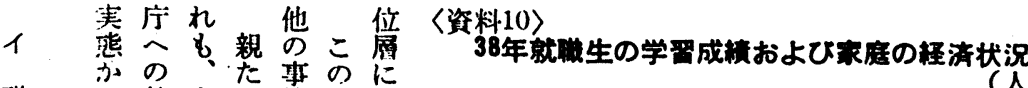
職 万就上ち情こあ

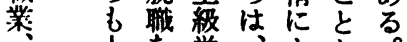
学分願学交占台 歴推っ䒘亮 剆ての和校就 ナい進の進㢺 主学将学生 ここそ来不在 病のし異能成 でこて常な續 流定先家 期花部 世的にの另 带収期以重 主入街な゙ のをれっ 希あ持かて 望るっで下

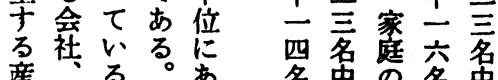
産官る。多名客客

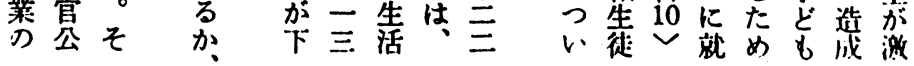

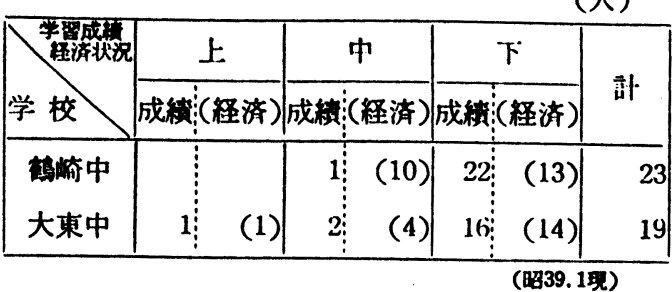

名程成名てをは職でへに增て

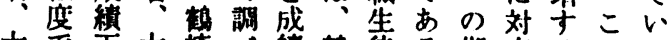

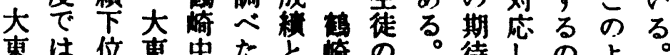
東愔位東中と、崎の待しのよ 中、群中学も実そへたはう

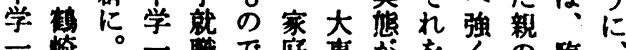
一崎。一職で庭東方をく䧗 九中杂生あの耐あ裹中海离 名学た名徒る生中る等ま薂枯

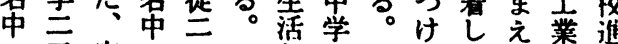

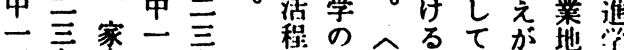

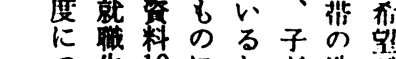




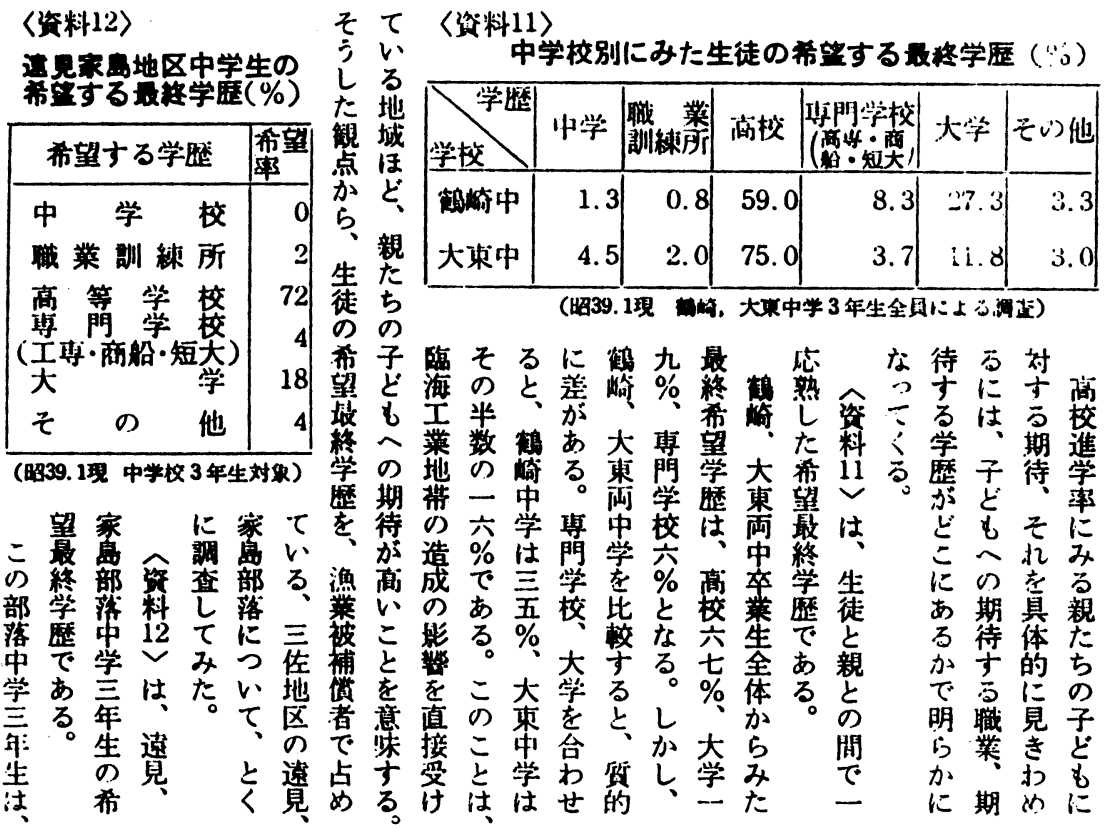

〈资料13〉

\begin{tabular}{|c|c|c|c|c|c|c|c|c|}
\hline \multicolumn{2}{|c|}{ 学区 联 } & 虫業 & 商業 & 漁業 & 技尓者 & 会社員 & 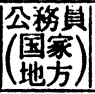 & その他 \\
\hline $\begin{array}{l}\text { 酾 } \\
\text { 中 }\end{array}$ & $\begin{array}{l}\text { 三 佐 } \\
\text { 就 崳 }\end{array}$ & $\begin{array}{l}2.5 \\
0.5\end{array}$ & $\begin{array}{l}2.5 \\
7.0\end{array}$ & $\begin{array}{l}1.0 \\
2.0\end{array}$ & $\begin{array}{l}24.0 \\
25.0\end{array}$ & $\begin{array}{l}58.0 \\
44.0\end{array}$ & $\begin{array}{l}7.5 \\
6.5\end{array}$ & 15.0 \\
\hline $\begin{array}{l}\text { 大 } \\
\text { 東 } \\
\text { 篎 }\end{array}$ & $\begin{array}{l}\text { 高田 } \\
\text { 松 阙 }\end{array}$ & 3.0 & $\begin{array}{l}6.0 \\
3.0\end{array}$ & 2.5 & $\begin{array}{l}27.5 \\
25.0\end{array}$ & $\begin{array}{l}43.5 \\
52.0\end{array}$ & $\begin{array}{r}10.5 \\
2.0\end{array}$ & 15.0 \\
\hline
\end{tabular}

芜筆六中 学業分職灾学

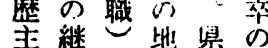
義张索区内み とな余心化 なと倿住他皆 っ考な民主無 たえくは费で

(明39.1理) 队杂机志村! がずたき帒。

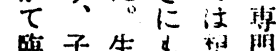

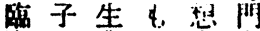
有地業は会生で八は合どこは待地業导開心念校

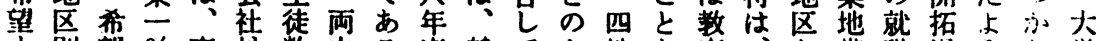

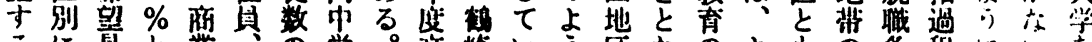

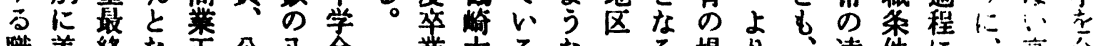

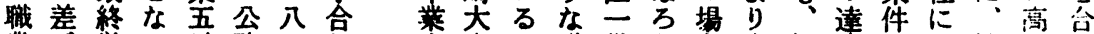

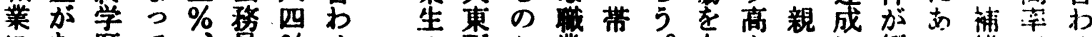

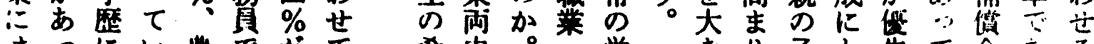

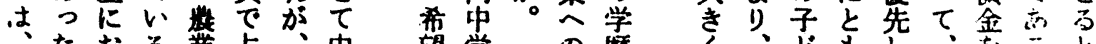

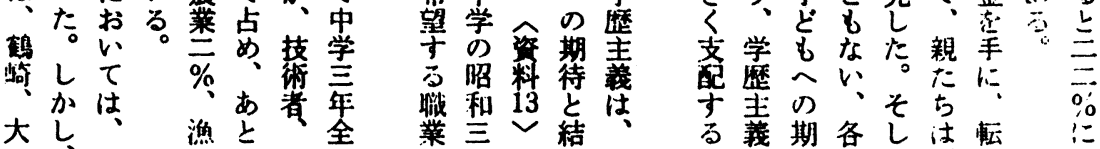


そえめ松て

も、低查地る添た

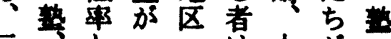

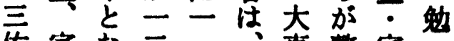
在家な三方東整家

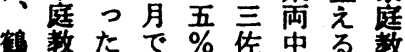

的篩のあと地学学師強

とにかり、な亥習

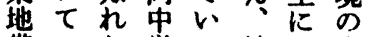

善いな学る鹤つ中

のるいと。踦いに

造者。㫐地ては

影る台垍 \%整整

蔡こ、莱莱まあ

がと補の高たり

强は習最田は。

以見拿地家家

地の受期欧庭庭

区がけで 三教教

ほせてあ師師

どないっ吾にが

䅹、るるた
業以知両七\% 生境

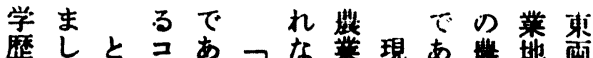

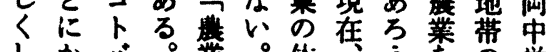

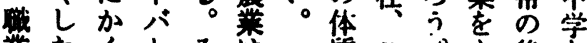

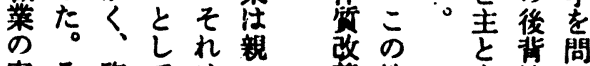

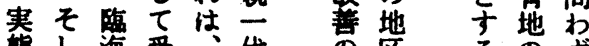

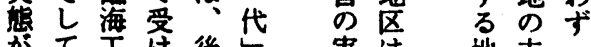

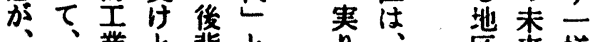

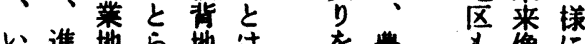

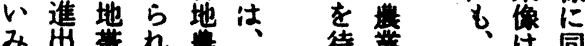

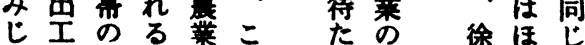
く场造。地の方体市洫 6に成带地、焎に推向 そーはの菠萧测に れ切おの の善菜さあ をの地机親代老采れる

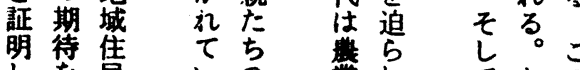

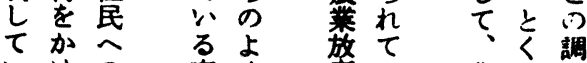

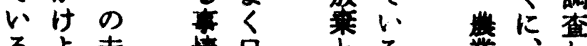

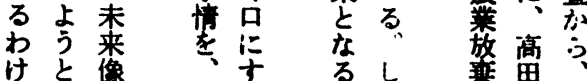

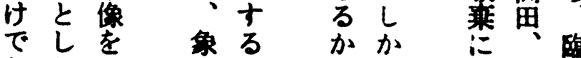

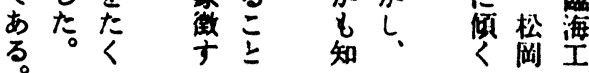

親あし、英映带市いてま分て

のるこ数て焦いたたい

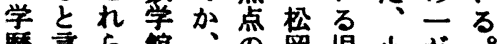
麾わ言馆、の岡临小が地学通さ 竜れ势田円だ区校望き 吕る。它光け四三六交 ら。整寺に立年ま実

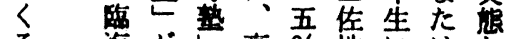

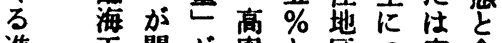
隻学閏が事々区つ寀合 学業設いでな二い庭わ 準地さちあう一て整せ

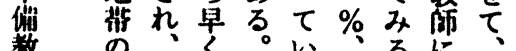

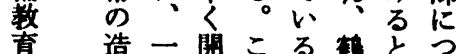

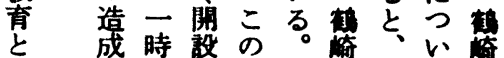

し $の$ 期さ地三地盐て中

〈资料14〉

芙・敞のみに无望している。

同，大來中学 1,2 年生の实虫

\begin{tabular}{|c|c|c|c|}
\hline \multirow{2}{*}{\multicolumn{2}{|c|}{ 学校・学年 }} & \multicolumn{2}{|c|}{ 熟に通っている者 } \\
\hline & & 人 数 & $\%$ \\
\hline \multirow{2}{*}{$\begin{array}{l}\text { 整 } \\
\text { 笴 }\end{array}$} & 1 年 & 88 & 29.2 \\
\hline & 2 年 & 73 & 20.6 \\
\hline \multirow{2}{*}{$\begin{array}{l}\text { 東 } \\
\text { 占 }\end{array}$} & 1 年 & 12 & 0.8 \\
\hline & 2 年 & 50 & 30.0 \\
\hline
\end{tabular}

年

年 的

さら市 万よ ら 泣 若な 华隻

て 集はれ区传区步学

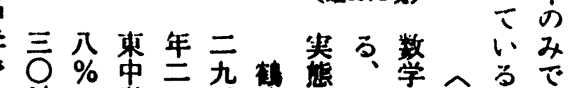

の势行たに地想まるで

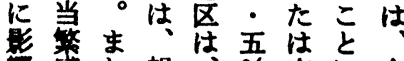

$\% \frown$ 学二\% 渏

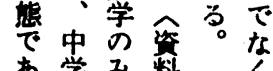

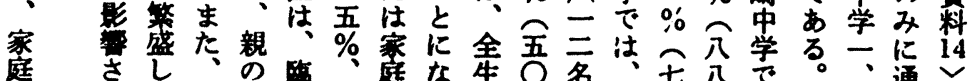

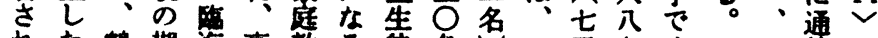

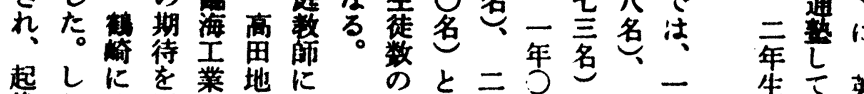

そ起しに危業地に

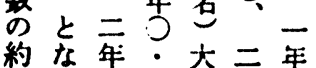


〈等料15〉

小学校 6 年生について“自分だけの机、.....

\begin{tabular}{|c|c|c|c|c|}
\hline & 三传小 & 崎小 & 高田小 & 松岡小 \\
\hline 臬分だけのい怄 & $80.5 \%$ & $79.5 \%$ & $77.0 \%$ & $73.5 \%$ \\
\hline
\end{tabular}

待机亶ま海松\%分実の 部

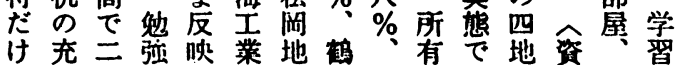
て足三部し地区崎地津あ区料机㻴 な事\%庄下带七地区去る。15境 くのでのい造三区別、。各とどを 高克方成立に四少はの物 之心る是。五九 地学程的 机の。翗影\%。る 校三度条

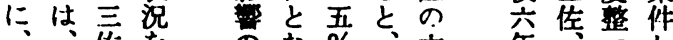

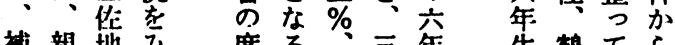

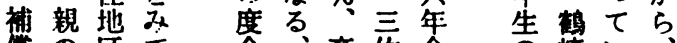
供の区て 合、高传全

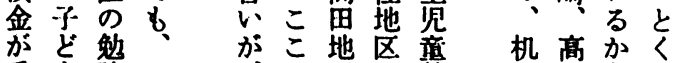

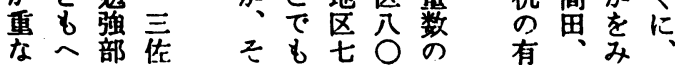

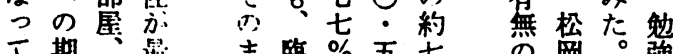

〈资料16〉

小学校 6 年生にみられる「子どもの学翼壳欲」

\begin{tabular}{|c|c|c|c|c|c|c|}
\hline & 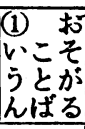 & 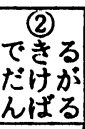 & $\begin{array}{c}\text { (3) } \\
\text { 気にか } \\
\text { 况る }\end{array}$ & 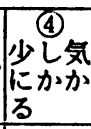 & $\mid \begin{array}{c}5 \\
\text { (5きら } \\
\text { める }\end{array}$ & 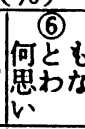 \\
\hline 佐 小 & 21.5 & 60.5 & 9.0 & 9.0 & 0 & \\
\hline 崎 小 & 21.0 & 60.0 & 11.5 & 3.0 & 0.5 & \\
\hline & 21.0 & 56.0 & 12.0 & 6.0 & 0 & \\
\hline 岡 小 & 23.5 & 33.5 & 10.5 & 27.5 & 0 & \\
\hline
\end{tabular}

(明39.1现)

でをな皘った年高

欲加 $\tau$

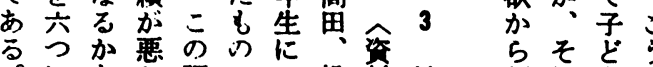

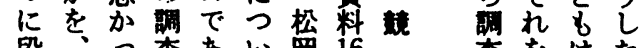
段冷あい岡16

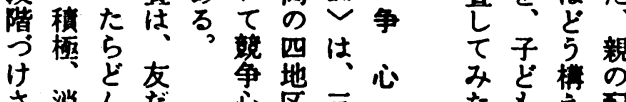

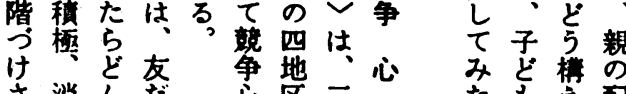

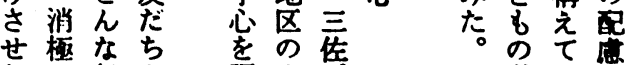
たの気よ調小 毛禹持鸟查学 の站に成六跲 学认沱 翼了対

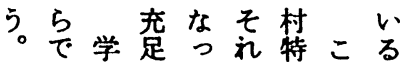
も垍事た汇有の加 摆と。刺の地 ら 親境な知激密区で のをっ畒さ集のあ 整た部杂地售る。 育的の屋、带民 に正被は和 対物あ的蒱四補 万的る。新集四供 関件案以五の 心少外年使 がら設のの途 、み計家間は 加に庭に に少組ま家 高、みで新の 心こ 入 政 かの れ住案改 、眮 5 居家築 十查れ堂檿 分のた整で始 想筑た色生 像再的艺。 れみ高占れた よか心にた漁 


\begin{tabular}{|c|c|c|}
\hline 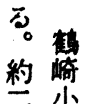 & 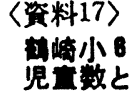 & $\begin{array}{l}\text { E生の転入 } \\
\text { 云入の时期 }\end{array}$ \\
\hline $\begin{array}{l}\text { 尤学 } \\
\% \text { 校 }\end{array}$ & 転入学年 & 筧童数 \\
\hline & 1 年 & 4 \\
\hline & 2 年 & 6 \\
\hline & 3 年. & 5 \\
\hline $\bar{\tau}$ & 4 年 & 17 \\
\hline \pm & 5 年: & 10 \\
\hline 名 & 6 年: & 7 \\
\hline 分 そ & 洲 & 49 \\
\hline
\end{tabular}

萑でか柗馬舎親はに 崎枟こ者場罊の 小入の 氏 外入西要低

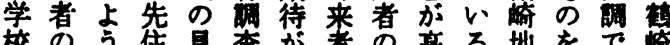

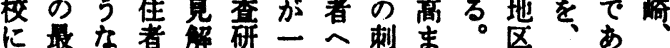

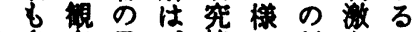
多子

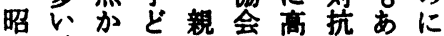

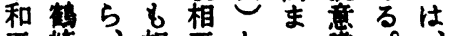
三劄 相 年区㘼 かを刺係

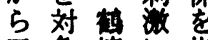

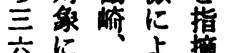
孪椆高る占揞 の)查田竸た

当四あそ愳て和を転五し笔し

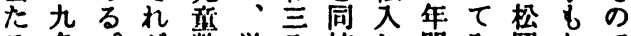
る名。が数学分校し間み岡あで

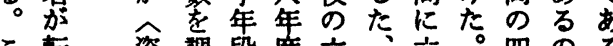

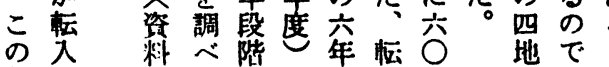
数睍 はで $17 \div$ 別に生入-

でな慗い昭炾全

区.は し

のなか 学あ
の地る高 八区。田 然亏の \%に书各 み心地 离て它希 地圾 5 区 8 の高つ様 七いでに 七のき稹 \%はる柾 、た的 松三けで 岡在分谅 地地んく 区区ば はのる枟 五分梳 正地 $\%$ \%
急何がさ が〈资料18〉

激かはれ進一 で、た学っ

あ変しが希の 呪の学集成模

則て 5 望要

た的、强

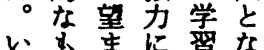

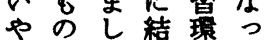

急を心合境て

な速感謷し

進なの呪争の

展いあ童心で

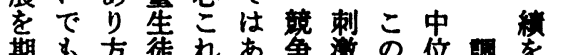

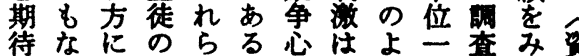

し、な生はまの見亏六結た料

て。后活高の生名果 \&18

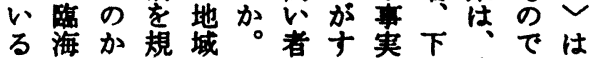

のエ

た業 5 し 社

こ带加き会

ののたた 境

与造ここ原

なは任れ配
分方位成

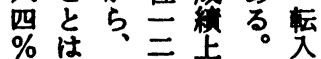

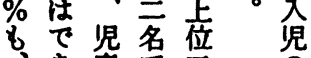

こな竟な゙三

辺告想る名
学
の社も転集つソ檕級 6 員成入竸各雷たジに

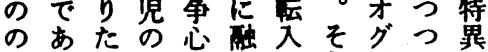
成りっ刺で合でうラあな

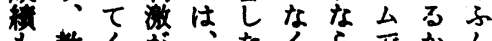

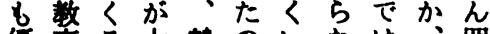

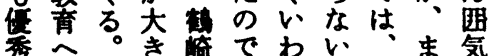

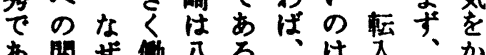

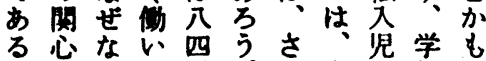
七 5 \% \%さ上級し 高ばいとだき非のだ

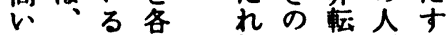
とこの地枟入入間に 盲の加 わ地名の 九域知最 るのれ高 ・枟な薄 し入いあ 加者。っ 当气た

枟部しこ 入分たれ 呪星予任 气会想

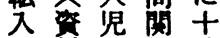
料係分 学 17 の 元 年 棸問あ ごに偯整る。 そ成に。 渐生机の 增占萛る。 で転せしな あ入なか澌 り、がしに 


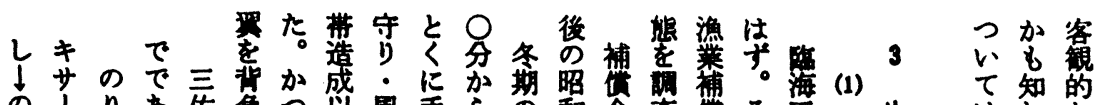

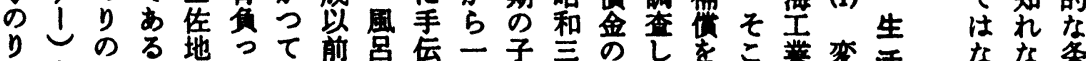

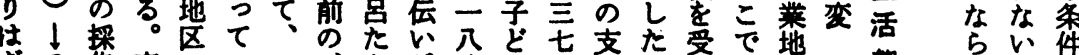

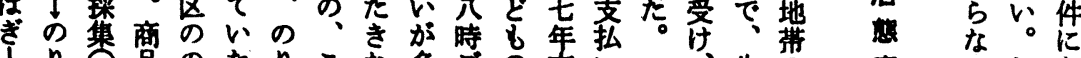

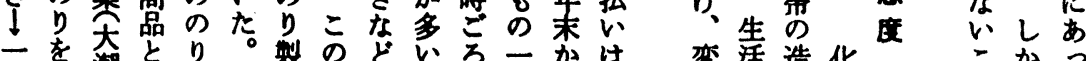

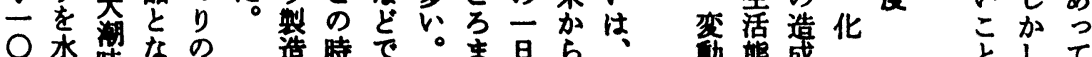

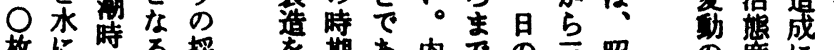

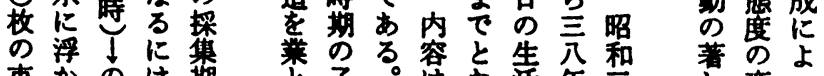

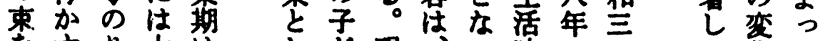

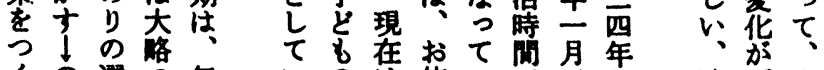

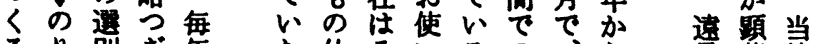

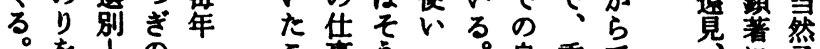
をりの二こ每う・自季で マのよ一ろ内芮炊小邑節あ

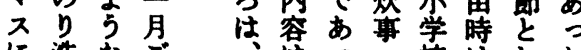

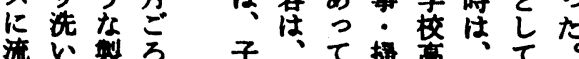

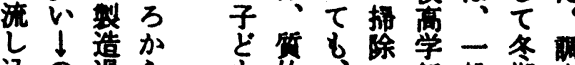
り程牭恠に

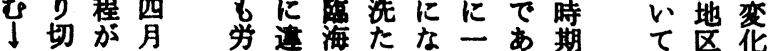

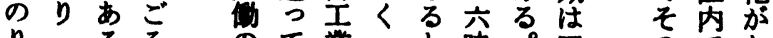

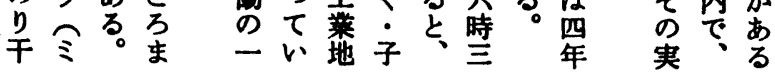

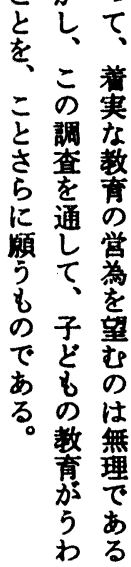

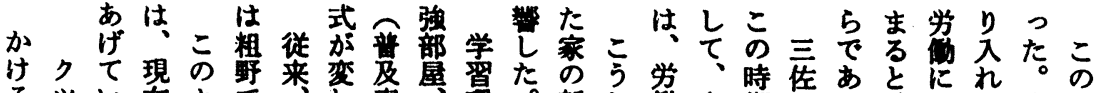

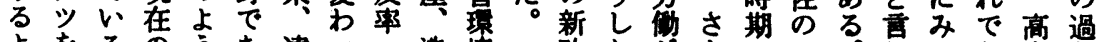

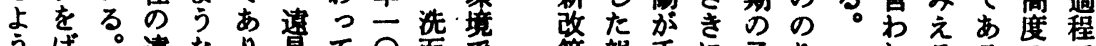

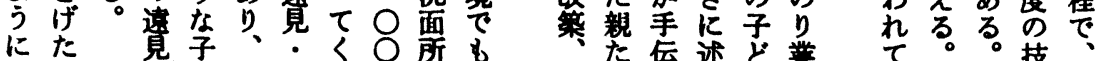

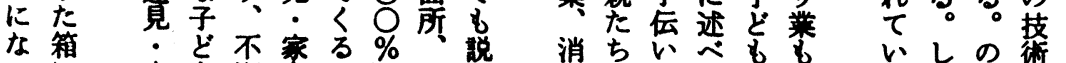

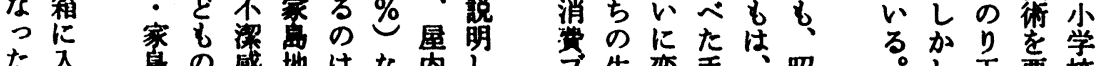

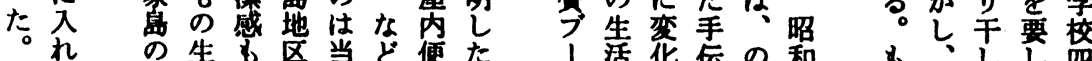

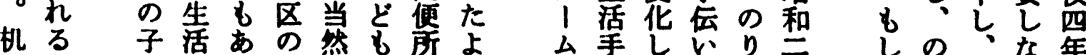

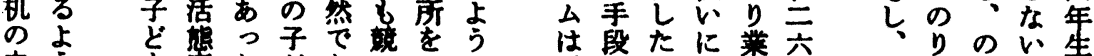

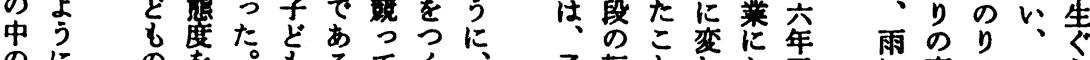
のにの老。るるてく転と加年整商ののら

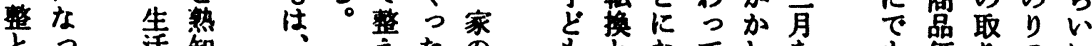

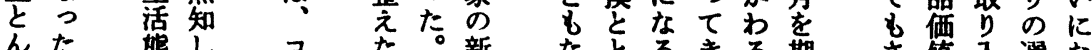

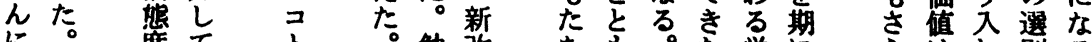

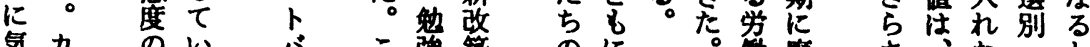
気力 の

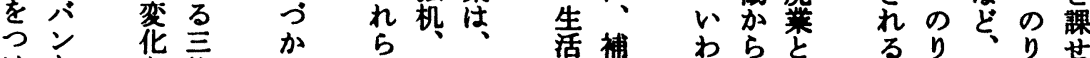

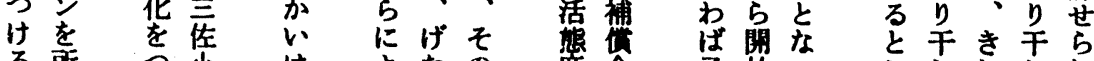

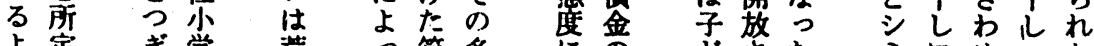

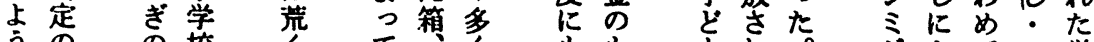

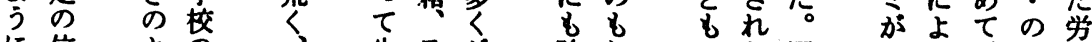

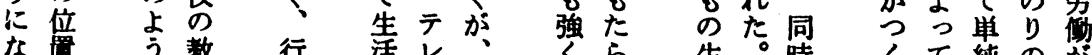

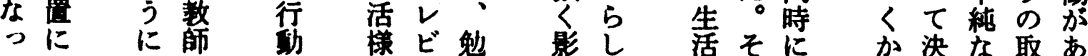
に師峌様ビ勉影し活そに视な取あ 


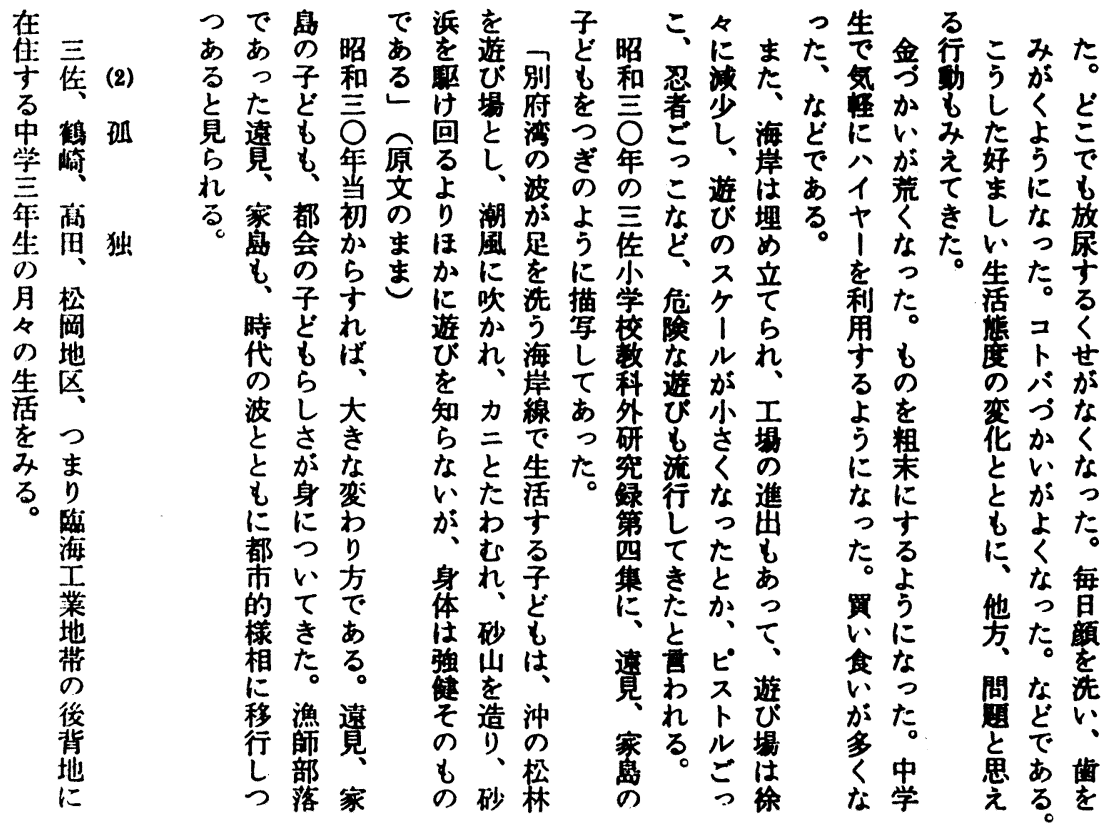

子造る克た专三だ〈资料19〉

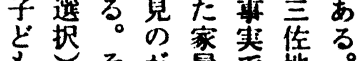

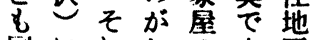

同に机しの十区

志あがて新分に

がら、な改で现

反わ三ら筑あ独

発机佐なか乃な

して小心らう中

合学の<。学

うる校はる学生

て。六、学歴

友年家習主: 多

た人生相偯菉い [ii] A 互境 $之 こ$ 他热学艻に進と の儿級瑓よ学は 学租女拈る淮 級中尒に拘㑛こ に元り り束謷れ 、組シつあすで

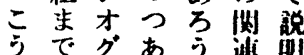
し補亏るす非 た满公こ㐫た

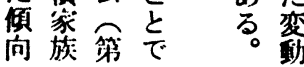

中学 3 年生で友人か全然ないと 回答し生徒

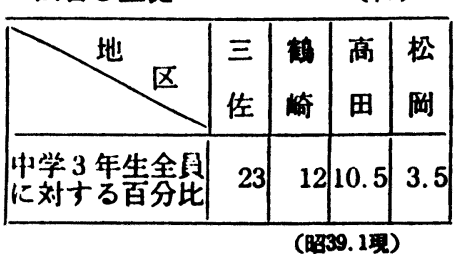

は凮一あい 地三る。 造成兰 占学 的商传答年 琵吾思地し生 整 \% 地区たで ので区三もつ 度あ二三心友

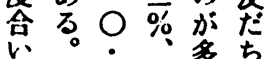
そこ吾鹤いが の の \% 崎こ全 ま実地と然 ま䈍松区でな
区.

的气势察学部 にのを教校分 走傾に箱告は 留と活 て㤎?立年き る以眠规 よと面 のよ

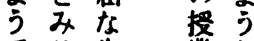
あ゙る生菜週 る個の補程

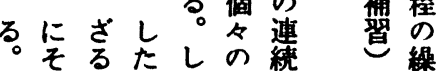
のをがか生で返

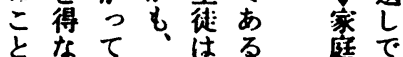
がい生き文。生は 端。徒わ仕と活な 的つ相め組く にぎ互て充に家だ あのは㫦机三庭乃 ら整别た传学う

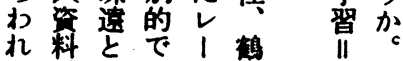

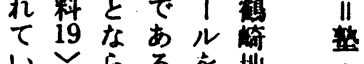


济

刀了煙

題

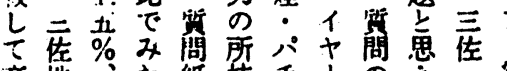

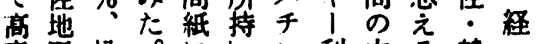

事区松。汇利内る十

だ凩結よのコ筩容行踦题

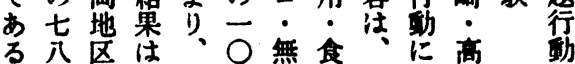

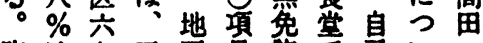

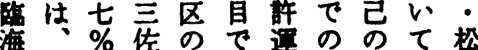

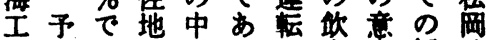

業想あ区学る。食志絽地

地さっ七三無六に界区

带れた分年断買よ蛅の

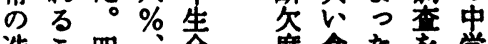

造气四全席食た竞

成と地地賣

にと区椅に

当は全地対

家以场行年

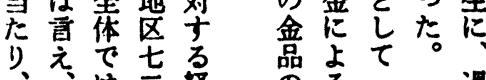

直他六\%筷 持加学去

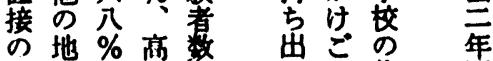

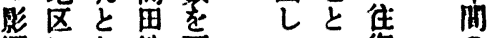

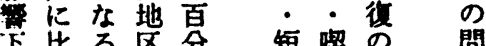

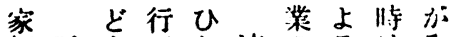

相现をでと連のるは

(8) 互独があり带開漁らら

のとあるの感拓莱生机

連なる。生はを䧹そ

带る。や活薄し、廃のう

感中方圈机、业仕で

の学てのた既組あ

ち生市確。にそかる

緩字民立、四し的。

生性加や年家遠

徒孞優必を補相見

影個身先要経供五。

名にし方過金の家

のてなしを連島

て生 いきくた手带部

万萿てたな。感落

の程る漁た個あ漁

でかで民の施業

はら分た人た变

あく 万解。 の。作

るるう。む密し

ま断。慮し䓌か上

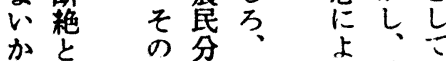

かと少解山文造に

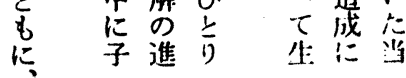

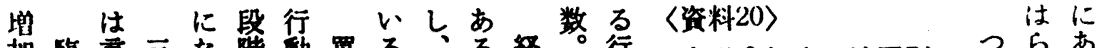

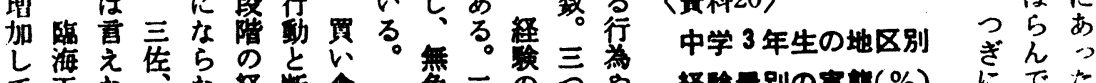

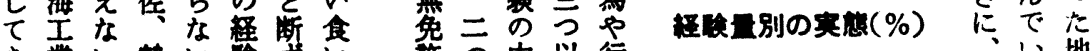

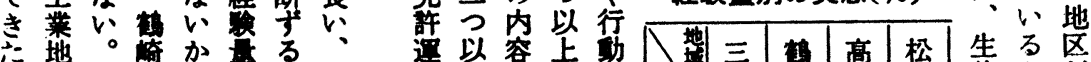

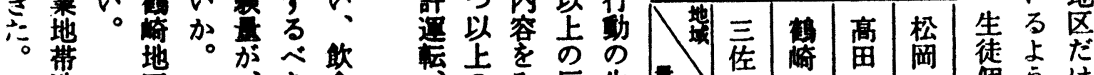

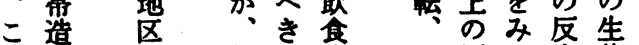

机成に行で店た反る磨徒

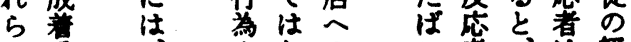

に手やなの者湿䖽

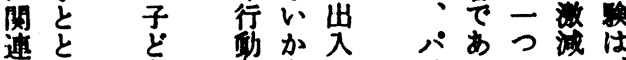

ᄂに

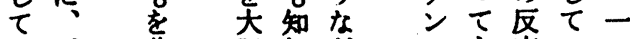

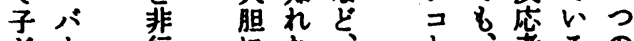

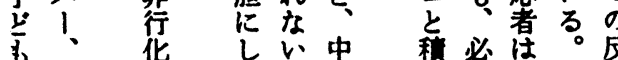

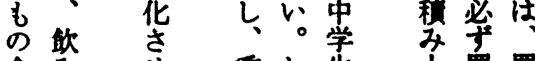

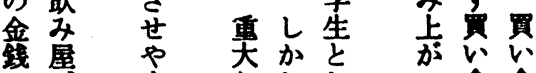

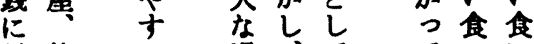

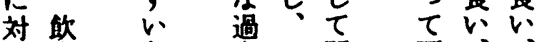

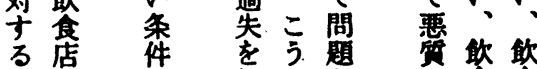

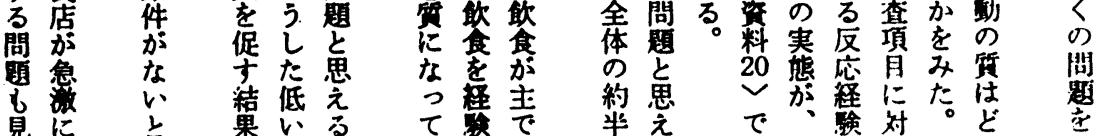

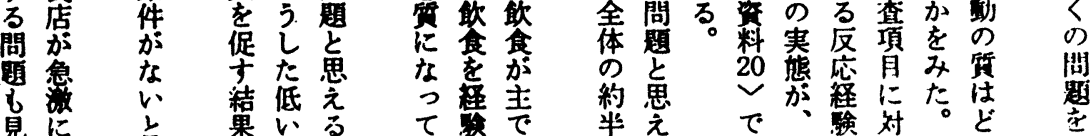

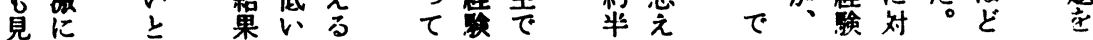




\begin{tabular}{|c|c|c|c|c|c|c|c|c|c|c|}
\hline \multicolumn{6}{|c|}{ 内容の組み合わせ } & 严 & 榙 & 裔 & 松 & 竍 \\
\hline 1 & 實い食い & 食 & 堂 & 無免吘運枟 & ゲーム沪金 & 2 & & & & 2 \\
\hline 2 & 買い食い & 食 & 堂 & ハイヤー & ゲームに金 & 1 & & & & 1 \\
\hline 3 & 買い食い & 食 & 堂 & ハイヤー & 刃 物 & 1 & & & & 1 \\
\hline 4 & 買い食い & 学柿 & を & $\begin{array}{l}\text { 家の全品の } \\
\text { 持 } 4 \text { 出し }\end{array}$ & 刃 物 & 1 & & & & 1 \\
\hline 5 & 買い企い & 食 & 堂 & ハイヤー & 学校茑 & 1 & 1 & & & 2 \\
\hline 6 & 買い食い & 食 & 堂 & 無免許運枟 & ゲームに食 & & 2 & & & 2 \\
\hline 7 & 買い食い & 食 & 堂 & 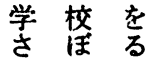 & 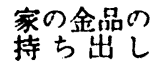 & & 1 & & & 1 \\
\hline 8 & 買い食い & 食 & 堂 & 無免許運転 & た壮こ & & 1 & & & 1 \\
\hline 9 & 買い食い & & 堂 & ゲームに金 & たばこ & & 1 & & & 1 \\
\hline 10 & 買い食い & 無免許運 & & 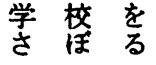 & $\begin{array}{l}\text { 家の金品の } \\
\text { 持 } 5 \text { 出 }\end{array}$ & & 1 & & & 1 \\
\hline 11 & 買い食い & 無免許運 & & ゲームに金 & 家の金品の & & 1 & & & 1 \\
\hline 12 & 無免許運転 & ゲームに & & たばこ & 刃 物 & & 1 & & & 1 \\
\hline 13 & 買い食い & 食 & 堂 & 無免故運枟 & 学校索 & & & 2 & & 2 \\
\hline 14 & 買い食い & 食 & 堂 & 無免許運転 & $\begin{array}{l}\text { 家の金品の } \\
\text { 持 } 5 \text { 出 }\end{array}$ & & & 1 & & 1 \\
\hline 15 & 買い食い & 食 & 堂 & パチンコ & 学校 る & & & 1 & & 1 \\
\hline 16 & 買い食い & 食 & 堂 & ハイヤー & 無免許運転 & & & & 1 & 1 \\
\hline
\end{tabular}

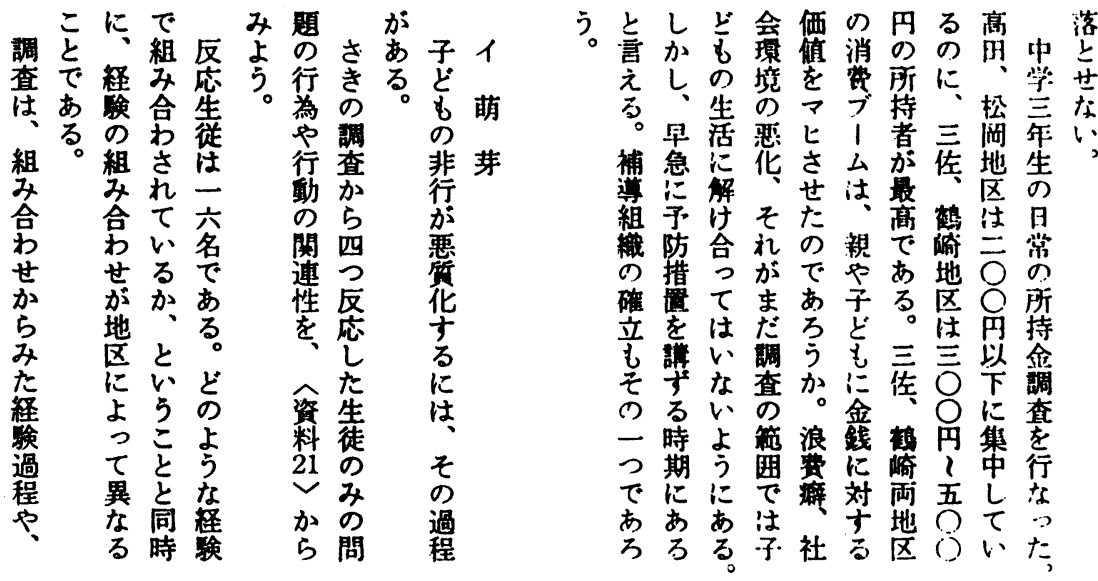




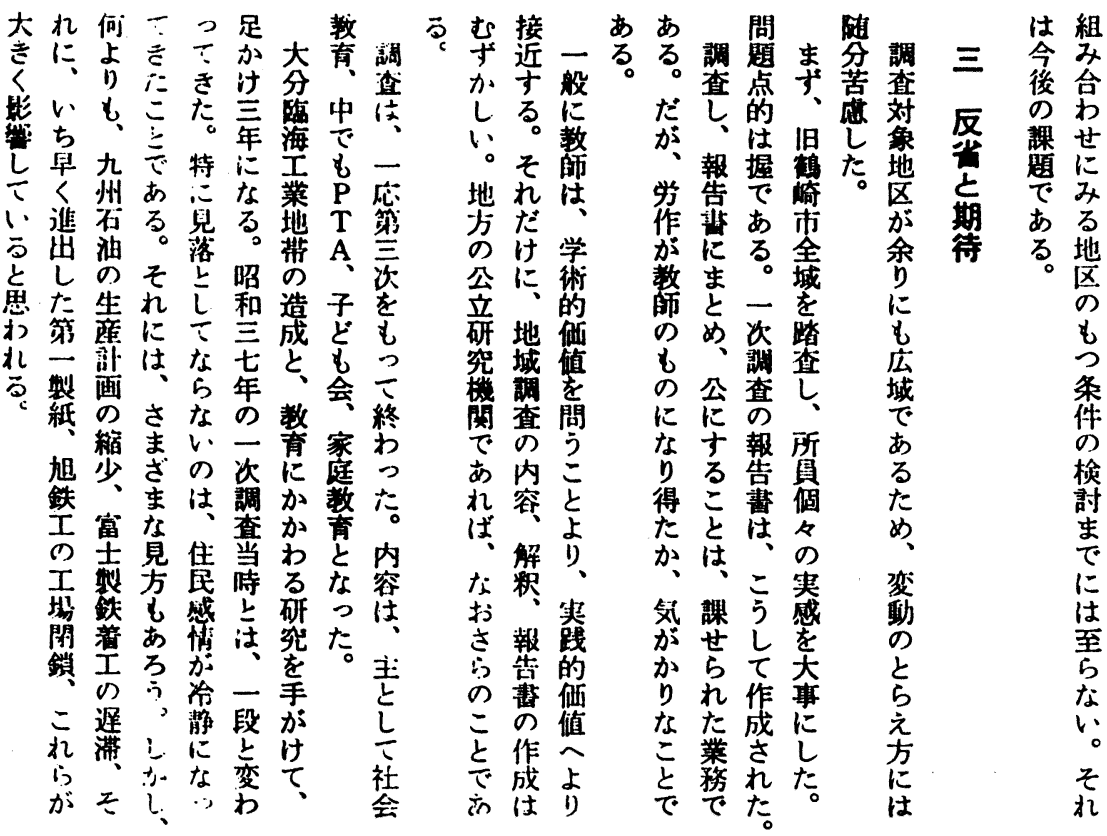

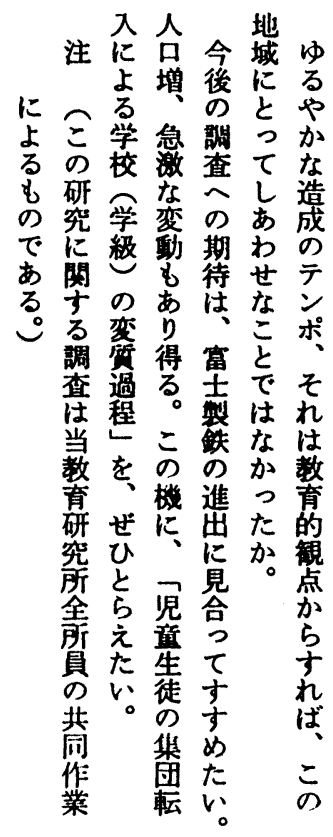

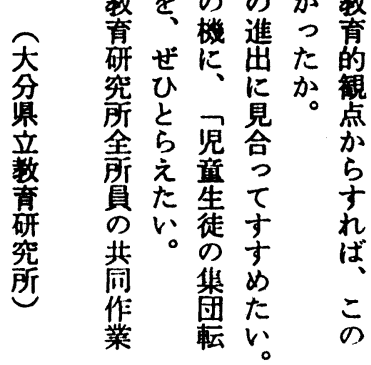




\section{The Attitudes of the Youth Engaged in Agriculture Towards Industrial Development in the Tohoku District}

Seiya Ema

Takeshi Katsumata Yoshihisa Yukie

(Tohoku University)

In putting the regional development into effect especially in this district, it is necessary to consider agricultural conditions. We promote the industrial development in this district in considering the change in agriculture. It is important to know the opinion of the farmers about the industrial developinent and about the future of agriculture. In the consideration of the educational program under such industrial conditions in the Tohoku district, the attitudes of the farmers themselves must be analyzed.

The youth engaged in agriculture in Miyagi Prefecture was surveyed. In the first section, the problems and the method of approch were examined. The movement of the graduates from lower secondary schools was discussed in the ncxt section. In the third section, the attitudes of those who have been clinging to agriculture were analyzed. The conclusion obtained was described in the last section.

\section{Parent's Pose and Children's Life}

\section{-A case of Tsurusaki in Oita Coastal Industrial Zone- \\ Tatsunori Iwamoto (Institute of Educational $)$}

Our purposes are to catch the influences that the process of industrialization have on the aspect of education, and to increase educational consciousness of its inhabitants.

The study was made in the City of Tsurusaki. The questionnaires were sent out to all the heads of the household, third year students in junior high school, and sihth year elementary pupils, and we analyzed them. 
Things that were considered were social environment, environment for study, and student's attitude of life. we expected to express as much as possible the present situation, comparing present with past and characterizing each zone.

\title{
Relation between the Graduates of the University and College and the Industrial Structure
}

\author{
Takasi Kagoyama \\ Shoji Koike \\ (Hokkaido University)
}

This report is a study concerning the relation between the industrial structure and higher education based on the 1950 a nd1960 census. From 1950 to 1960, the industrial structure in all prefectures of Japan was changed with the same propotion and the same direction.

In some profectures the graduates of university and college was increased but in other prefectures it was decreased. The increase or decrease in the prefecture was not correlated with numbers of employed persons.

\section{A Study of School Careers}

\section{Akira Harada Yasumasa Tomota (Hiroshima University)}

One of the factors that rhecks the realization of meritocracy in Japan is to attach too much importance to a school career. A person with an inferior educational career, that is, no higher education or education in less famous institution, in most cases, has to give up his effort or ambition. As school careers are acquired through the rigid entrance examination, to select candidates through their school careers is, in a sence, rational. But, if one's ability continues to be evalated fixedly through his life by his educational background, school careers function rather as ascription than as achievement, for one's ability itself is changeable and the abilities required at school are not necessarily the abilities required in one's place of work. 